\title{
De nuevo sobre Pedro de Aponte, PINTOR DEL PRIMER ReNacimiento en ARagón
}

\section{"Coming back once more to Pedro de Aponte, Early Renaissance painter in Aragon"}

\section{Alberto Velasco Gonzàlez ${ }^{1}$}

Mira a Pedro del Ponte, en quien florece al sol de sus virtudes Daphne ingrata,

y si lauro en sus sienes reverdece, diadema en ellas su esplendor retrata. (Juan de Moncayo y Gurrea, Marqués de San Felices, 1656)²

Recibido: 03-08-2020

Aceptado: 25-09-2020

\section{Resumen}

El presente estudio aborda la personalidad del pintor Pedro de Aponte (doc. 1502-1530), uno de los principales representantes del Primer Renacimiento en Aragón y autor de los retablos mayores de las iglesias de Grañén (Huesca), Ágreda (Soria), Cintruénigo (Navarra) y Olite (Navarra), entre otros. Uno de los objetivos del artículo es dar a conocer la única fotografía conservada del retablo mayor de la iglesia de Azanuy (Huesca), conjunto parcialmente destruido durante la Guerra Civil española. La localización de la imagen ha permitido identificar, además, dos compartimentos de dicho retablo que se salvaron de la contienda bélica, hoy conservados en el Museo de Zaragoza. El retablo de Azanuy era un trabajo documentado (1509), con lo que los hallazgos suponen la incorporación de una obra más al corpus conocido del pintor. Por otro lado, el artículo añade al catálogo de Aponte un nuevo retablo al que pertenecieron dos compartimentos hoy conservados en el Museu Nacional de Arte Antiga de Lisboa y en una colección particular.

Palabras clave: Pedro de Aponte, Renacimiento, pintura, Azanuy, Zaragoza.

1 Universitat de Lleida, alberto.velasco@udl.cat. Este trabajo se enmarca entre los resultados del proyecto de investigación "El poder vivido en la baja edad media: percepción, representación y expresividad en la gestión y recepción del poder (PV-PRE)” (ref. PID2019104085GB-100, Ministerio de Ciencia, Innovación y Universidades, investigador principal: Dr. Flocel Sabaté, Universitat de Lleida), así como del grupo de investigación consolidado en Estudios Medievales "Espai, Poder i Cultura" (ref. 2017 SGR 00043, Generalitat de Catalunya, investigador principal: Dr. Flocel Sabaté, Universitat de Lleida). La investigación ha contado con la indispensable ayuda de la Dra. Carmen Morte que, en tiempos de pandemia y encierro, me ha cedido desinteresadamente numerosos materiales indispensables para el desarrollo del trabajo que aquí presentamos. Desde estas líneas, mi más sincero agradecimiento por su generosidad y constante disponibilidad antes mis impertinentes demandas. Finalmente, queremos hacer constar nuestro agradecimiento al Dr. Francesc Fité por su colaboración en la transcripción de los documentos que ofrecemos en apéndice. 


\section{Abstract}

This study delves into the personality of the painter Pedro de Aponte (doc. 1502-1530), one of the main representatives of the Early Renaissance in Aragon and author of the main altarpieces in the churches of Grañén (Huesca), Ágreda (Soria), Cintruénigo (Navarra) and Olite (Navarra), among others. One of the objectives of the article is to present the only preserved photograph of the main altarpiece of the church of Azanuy (Huesca), a set partially destroyed during the Spanish Civil War. The location of the image has also made it possible to identify two compartments of this altarpiece that were saved from the war, now preserved in the Museo de Zaragoza. The Azanuy altarpiece was a documented work (1509), with which the findings suppose the incorporation of one more work to the known corpus of the painter. On the other hand, the article adds to the Aponte catalog a new altarpiece to which two compartments belonged, now preserved in the Museu Nacional de Arte Antiga in Lisbon and in a private collection.

Keywords: Pedro de Aponte, Renaissance, painting, Azanuy, Zaragoza.

Pedro de Aponte (doc. 1502-1530) es uno de los grandes representantes de la pintura aragonesa de la primera mitad del siglo XVI. Desde que su nombre se elogiase por primera vez en los versos del Marqués de San Felices que encabezan este artículo, o en las exageradas - y muy citadas - palabras del tratadista Jusepe Martínez ${ }^{3}$, su figura creció de forma desmesurada y ficticia dibujando una personalidad que no se ajusta ni a la realidad de su trayectoria, ni a la calidad de su pintura. El suyo es uno de los escasos nombres de artista que la tratadística hispana de época moderna recuperó del último gótico y del Primer Renacimiento. Se le supuso una especial habilidad como retratista nunca demostrada, y se le consideró como alguien cercano a los Reyes Católicos sin que ello se documentase. Una consecuencia del perfil mítico y equívoco que dejaron esbozado estas primeras menciones del pintor la hallamos en el sinfín de atribuciones que se hicieron a Aponte durante la primera mitad del siglo $\mathrm{XX}$, incluyendo en su catálogo trabajos que hoy se relacionan con pintores tan dispares como Tomás Giner, Bernardo de Arás, Juan de la Abadía o Pedro Díaz de Oviedo, entre otros.

Nada de lo que se dijo de él en el siglo XVII parece cierto a la luz de sus obras conservadas y de lo que nos dicen los documentos, que nos lo presentan como pintor de cierto éxito especializado en la pintura de retablos, y que hace gala de un estilo que ni mucho menos llega a las cotas de calidad que se había supuesto. Afortunadamente, desde finales de los años setenta del siglo XX, los trabajos de Carmen Morte han situado su figura en el lugar que le corresponde gracias al expurgo de nuevas

3 MARTÍNEZ, J. Discursos practicables del nobilísmo arte de la pintura. Madrid: Akal, (edición a cargo de Julián Gallego), 1988, p. 179. 
noticias archivísticas y de la asociación de las mismas a diversas obras conservadas ${ }^{4}$. A los trabajos de dicha investigadora deben añadirse los de otros especialistas que han contribuido a dibujar un perfil todavía más nítido de la trayectoria artística del pintor ${ }^{5}$.

\section{Pedro de Aponte no es el autor del retablo mayor de Bolea}

A pesar de lo que se ha avanzado en el conocimiento del pintor y su carrera profesional, la historiografia italiana ha continuado insistiendo en una hipótesis formulada en su día por Diego Angulo - partiendo de lo estipulado previamente por Ricardo del Arco-y desarrollada por Ferdinando Bologna, que identificaba a Pedro de Aponte con el pintor que realizó el retablo mayor de la colegiata de Bolea (ca. 1498-1503) y dos tablas con la Natividad y la Flagelación del Museo del Duomo de Atri (Abruzzo). Según Angulo y Bologna, el autor de estas obras será Aponte debido a que se le documentaba trabajando en la localidad aragonesa ${ }^{6}$. Y es justo ahí donde subyace el error de base, pues la deducción se ampara en la interpretación errónea de un par de documentos de 1507 y 1511 relacionados, respectivamente, con el trabajo de Aponte en Huesca y Grañén, en los que se mencionaba la actividad previa del pintor en Bolea. Aunque en ningún momento se afirma en ellas que él fuese el autor del retablo mayor, esas referencias dieron pie a Ricardo del Arco a identificar al anónimo Maestro de Bolea con Pedro de Aponte 7 . Paradójicamente, las verdaderas obras de este último pasaron posteriormente a incluirse en la producción de un pintor anónimo que fue designado como "Maestro de Ágreda"8.

4 Sobre Pedro de Aponte, véanse los estudios seminales de ARCO, R. del. El pintor cuatrocentista Pedro de Aponte. Tablas inéditas. Arte Español, 1914, 3, pp. 106-125; ARCO, R. del. Pedro de Ponte, o Aponte, pintor del Rey Católico. Boletín del Seminario de Estudios de Arte y Arqueología: BSAA, 1942-1943, tomo 9, pp. 59-77, a los que siguieron los diferentes trabajos de la profesora Carmen Morte. Véase MORTE, C. La personalidad artística de Pedro de Aponte a través del retablo de San Miguel de Agreda (Soria). En: Primer Coloquio de Arte Aragonés. Teruel: Diputación Provincial de Teruel, 1978, pp. 219-234; MORTE, C. La obra del pintor Pedro de Aponte o del Ponte en Navarra: los retablos de Santa María la Real de Olite y de San Juan Bautista de Cintruénigo. Príncipe de Viana. Anejo, 1986, 2-3 (Homenaje a José María Lacarra), pp. 565-590; MORTE, C. Pedro del Ponte o Aponte. En: Aragón y la Pintura del Renacimiento. Zaragoza: Museo e Instituto "Camón Aznar", 1990, pp. 65-78; MORTE, C. El retablo mayor de la iglesia parroquial de Grañén. En: El retablo de Grañén. Huesca: Diputación de Huesca, 1992, pp. 17-84; MORTE, C. Los maestros del retablo de San Miguel de Ágreda. En: El retablo de San Miguel de Ágreda (Soria). Historia y restauración. Soria: Caja Salamanca y Soria, 1997, pp. 39-59; MORTE, C. El retablo. En: El retablo de San Miguel de Ágreda (Soria). Historia y restauración. Soria: Diputación Provincial, 1997, pp. 63-109; MORTE, C. Pedro de Aponte en Bolea. Y una noticia de La Calahorra (Granada). Boletín del Museo e Instituto Camón Aznar, 1997, 67, pp. 95-122; MORTE, C. Historia. En: El retablo mayor de la iglesia de Santa María de Olite. Historia y conservación. Pamplona: Gobierno de Navarra, 2007, pp. 13-123; MORTE, C. Estudio histórico-artístico de una obra renacentista. En: El retablo mayor de la parroquia de San Juan Bautista de Cintruénigo. Historia y conservación. Pamplona: Gobierno de Navarra, 2009, pp. 11-78.

5 En cuanto a los estudios de otros especialistas, véase NAVAL, A. Pedro del Ponte (Aponte). Tesis de licenciatura inédita, Universidad Complutense de Madrid, 1975 (con autoedición reciente del autor [2017] en https://www.antonionavalmas.net/IMG/pdf/del ponte_definitivo_para_web_10-07-2018_.pdf) [consulta: 8 agosto 2020]; MARÍAS, F. El largo siglo XVI. Madrid: Taurus, 1989, pp. 207-209; CRIADO, J. Una obra desaparecida del pintor Pedro de Ponte. El retablo de la Virgen de Calcena. 1527. Tvriaso, 1996, XII, pp. 271277; BARRACHINA, J. Pedro de Aponte. Mare de Déu amb el Nen. En: La pintura gòtica hispanoflamenca. Bartolomé Bermejo i la seva època. Barcelona-Bilbao: Museu Nacional d'Art de Catalunya-Museo de Bellas Artes de Bilbao, 2003, pp. 292-295; CRIADO, J. Relaciones entre la Ribera de Navarra y Aragón durante la época del Renacimiento. Cuadernos de la Cátedra de Patrimonio y Arte Navarro, 2008, 3, pp. 223-224.

6 ANGULO, D. Pinturas del siglo XVI en Toledo y Cuenca. Juan de Borgoña y su escuela. Pedro de Aponte en Atri. Yáñez y Sebastián del Piombo. Archivo Español de Arte, 1956, XXIX, 113, pp. 51-54; BOLOGNA, F. Napoli e le rotte mediterranee della pittura. Nápoles: Società Napolitana di Storia Patria, 1977, pp. 215-236.

7 ARCO, ref. 4, p. 68. Cfr. MORTE, ref. 4, p. 222, que lo desmiente.

8 ANGUlO, D. La pintura del Renacimiento en Navarra. Príncipe de Viana, 1943, XIII, pp. 421-444. 
Con todo, en 1997 Carmen Morte dio a conocer una valiosa documentación que ponía orden al espinoso asunto de Bolea ${ }^{9}$. Así, nuevas informaciones demostraban que, a partir de 1503, y junto al también pintor Pedro Despiota, Aponte realizó en la iglesia de Bolea diferentes tareas, pero ninguna de ellas fue la materialización del retablo mayor, que solamente contribuyó a finalizar realizando tareas menores. Aponte y Despiota intervinieron muy puntualmente policromando algunas partes de la mazonería y las polseras. Pintaron asimismo las puertas que lo protegían, pero no actuaron en los compartimentos que integran el conjunto, que ya habían sido pintados por el anónimo Maestro de Bolea entre 1498 y 1503. Sea como sea, se menciona en la nueva documentación aparecida que tanto Aponte como Despiota habían trabajado anteriormente en la obra, aunque sin especificar qué labores llevaron acabo. Dado que su mano no se identifica en los compartimentos, se deduce que fueron tareas secundarias relacionadas con la finalización del proyecto, similares a las que ahora contrataban. La documentación publicada por Morte especificaba, además, que ambos pintores debían realizar el dorado de dos pares de bordones, las pinturas murales de la bóveda del templo y del arco junto al retablo mayor, además de otros dos retablos. Uno de ellos era el de San Juan, desaparecido, y el otro el de San Sebastián, afortunadamente conservado, que presenta una predela con escenas dedicadas a la vida de diferentes santos.

Por tanto, la identificación de Aponte con el retablo mayor de Bolea se basaba en un error de interpretación de la documentación que debía subsanarse. Sin embargo, y a pesar de las evidencias estilísticas y documentales, una parte de la historiografía italiana ha continuado insistiendo en esta hipótesis que se ha demostrado inviable y fútil. La fascinación de los especialistas italianos por la atribución de las "exóticas" tablas de Atri a un pintor hispano con nombre y apellidos, ha pasado por encima de cualquier lógica analítica. Y lo equívoco de la propuesta no se ha corroborado únicamente a partir de la interpretación correcta de los documentos aragoneses, sino gracias también al análisis del estilo de las tablas de Atri y del conjunto de Bolea, que nada tiene que ver con el de las obras documentadas de Aponte en Bolea mismo (retablo de San Sebastián), Ágreda, Olite o Cintruénigo, que son de inferior calidad y responden a planteamientos formales muy alejados. El pintor de Bolea, en cambio, es un maestro mucho más dotado, relacionado directamente con la pintura que pivota en Toledo alrededor de Juan de Borgoña. Sea como sea, y de forma inexplicable, diversos historiadores italianos han continuado insistiendo en la asociación triangular Atri-Bolea-Aponte, y lo han hecho al margen de lo publicado durante los últimos treinta años por la historiografía hispana, empeñados en el mantenimiento en pie de un castillo de naipes que hace tiempo se derrumbó ${ }^{10}$.

9 MORTE, ref. 4, pp. 95-122. Sobre el retablo de Bolea, véase también MORTE, C. Los retablos y sillería de coro en Santa María la Mayor. En: La villa de Bolea. Estudio histórico-artístico y documental. Zaragoza: Centro del Libro de Aragón, 2001, pp. 47-78; MORTE, C. El retablo mayor de la colegiata de Bolea (Huesca): una aproximación al dibujo subyacente a través de la reflectografía de infrarrojos. En: Ximo COMPANY y otros, editores. El rol de lo hispano en la pintura medietarránea de los siglos XV y XVI. Lleida: Centre d'Art d'Època Moderna, 2009, pp. 206-267; SRICCIA SANTORO, F. Tra Aragona e Napoli: ricerce sul "Maestro di Bolea". Prospettiva, 2009, 133, pp. 22-45.

10 Siguiendo la línea iniciada por Ferdinando Bologna, citamos como ejemplo el estudio de Pier Luigi Leone de Castris del Misal-breviario de Fernando el Católico (Roma, Biblioteca Apostólica Vaticana, ms. Chigi C VII 205) (LEONE DE CASTRIS, P. L. Atribuido al Maestro de Bolea (¿Pedro de Aponte?). Misal-breviario de Fernando el Católico. En: Los Reyes Católicos y la Monarquía de España. Valencia: Generalitat Valenciana, 2004, pp. 376-378). En dicho trabajo se da casi por hecho que Aponte estuvo en diversas ocasiones en Italia de la mano de Fernando el Católico, aferrándose a lo afirmado por Jusepe Martínez en el siglo XVII. De manera aún más sorprendente se asevera que "las obras que se le atribuyen con certeza [...] muestran notables puntos de contacto, aún con una hechura 
Para acabar de adobar la cuestión, desde lo defendido por Bologna se han atribuido al autor del retablo de Bolea y, por tanto, a Aponte, diversos manuscritos iluminados que, de manera colateral, han contribuido a un completo desdibujamiento —en Italia - de la personalidad artística de nuestro protagonista. Nos referimos a un manuscrito con las Epistole de Plinio (Nápoles, Biblioteca Girolamini CF. III. 6) ${ }^{11}$, el Misal-breviario de Fernando el Católico (Roma, Biblioteca Apostólica Vaticana, ms. Chigi C VII 205), cuatro Antifonarios y un Salterio de la Biblioteca de la Abadía de Montecassino y, finalmente, tres libros de horas: Biblioteca Nacional de Francia (ms. Latin 1354), Sotheby's (a la venta en 1911) y Biblioteca Trivulziana de Milán (ms. 440). A estos manuscritos deben añadirse diversas pinturas sobre tabla, como un Santo Tomás de la catedral de Ischia, un San Leonardo de la iglesia de Armento in Basilicata (robado en 1972 y recuperado en 2016), y una Virgen con el Niño aparecida hace años en el mercado londinense, entre otras ${ }^{12}$. Nada de todo ello puede, ni debe, atribuirse a Aponte, pues su estilo es diametralmente opuesto al de los retablos de Bolea (San Sebastián), Grañén, Ágreda, Cintruénigo y Olite, obras documentadas del pintor ${ }^{13}$. Otra cosa muy distinta, pero que dejaremos al margen debido a que se aleja del objetivo de este artículo, es que todos los manuscritos y obras italianas que se han relacionado con el retablo mayor de Bolea sean, en realidad, obra del mismo pintor.

Aquello que nos parece fuera de toda duda es que tanto la llegada de Pedro de Aponte a Aragón, como la realización del retablo mayor de Bolea, formaron parte de un mismo contexto protagonizado por diversos pintores castellanos que desarrollaron su actividad en tierras aragonesas. En este sentido, parece ser que Aponte era originario de la localidad zamorana de Toro, según afirmó su hijo, Pedro Jerónimo de Aponte, nombrado notario real por el rey Felipe II, y más adelante receptor en la Real Chancillería de Granada (1560): "Yo fui hijo de Pedro de Aponte, Vecino de Zaragoza, natural de Toro de Castilla, y de María de Arruego, hija de Juan de Arruego, y de Violante de Exea y Cuevas, de la generación de los Cuevas de Fuentes. Mi Agüelo Juan de Arruego era de Grañén natural"14.

Este origen toresano emplaza al artista en un ambiente especialmente atractivo desde el punto de vista de su formación, ya que lo sitúa en el área de influencia de diversos maestros castellanos del momento, como Juan de Borgoña de Toro, Lorenzo de Ávila y otros. De ese mismo contexto geográfico procedía,

más afanosa y corriente, con las obras del Maestro de Bolea y las pinturas o los códices miniados, entre Nápoles y Roma, para el Rey Católico, Acquaviva y los monjes de Montecassino". Curiosamente, Leone de Castris deja al margen "las más tardías de Ágreda (alrededor de 1519-1523), Cintruénigo (1526-1528) y Olite (1528-1530), así como el citado retablo menor de Bolea [el de san Sebastián] [...] y el de Grañén", es decir, todas aquellas que se apartan estilísticamente del retablo mayor de Bolea y Atri, y que son, en realidad, las únicas que salieron de los pinceles de Aponte. Un desarrollo más amplio del posicionamiento de dicho autor en LEONE DE CASTRIS, P. L. Pittura e miniatura nella Napoli di Ferdinando il Cattolico». En: Fernando CHECA y Bernardo GARCÍA, coordinadores. El Arte en la corte de los Reyes Católicos. Rutas artísticas a principios de la Edad Moderna. Madrid: Fundación Carlos de Amberes, 2005, pp. 75-94.

11 BOLOGNA, ref. 6, p. 232

12 Para sintetizar, remitimos a la monografía reciente de GAETA, L. Juan de Borgoña e gli altri: relazioni artistiche tra Italia e Spagna nel 400. Galatina: Mario Congedo Editore, 2012, pp. 75-88, que analiza la cuestión y recoge las posturas enfrentadas.

13 MORTE, C. El Maestro del Misal-Breviario Vaticano de Fernando el Católico. Boletín del Museo e Instituto "Camón Aznar", 2002, LXXXIX, pp. 261-286 y 409-428. También se descarta la autoría de Aponte en relación a los manuscritos mencionados en PERRICIOLI, A. Un "Libro d'ore" della Bibliothèque Nationale di Parigi e alcune riflessioni sull'attività di miniatore del Maestro del retablo de Bolea. Prospettiva, 1998, pp. 91-95.

14 LATASSA Y ORTÍN, F. Biblioteca nueva de autores aragoneses que florecieron desde el año de 1500 hasta 1599. Pamplona: Oficina de Joaquín fray Domingo, 1798, vol. I, pp. 374-375. 
con casi total seguridad, el autor del retablo mayor de Bolea, por lo que no deja de ser significativo que dos de los pintores más interesantes del primer tercio del siglo XVI en Aragón sean de origen castellano y procedan de un mismo contexto artístico. No sabemos si llegaron juntos y si vinieron formando parte de una misma cuadrilla para acometer el retablo de Bolea, pero si fue así, parece evidente que la voz cantante, el maestro principal, fue el autor del retablo boleano, a quien estarían supeditados el resto de pintores que colaboraron puntualmente en el proyecto, como Pedro de Aponte y Pedro Despiota.

La llegada de artistas castellanos a tierras aragonesas se documenta ampliamente desde tiempos del tardogótico con el arribo de maestros como Miguel Ximénez (Pareja, Guadalajara), los Vallés, Juan de Zamora, Bartolomé Bermejo (Córdoba), Fernando del Rincón (Pareja, Guadalajara), Fernando de Burgos, Juan Sesé, Juan de Ochoa, Juan Chamorro (Toledo) o Cristóbal de Cardeñosa (Ávila), entre otros ${ }^{15}$. Los dos últimos, además, en algún momento aparecen relacionados de manera directa o indirecta con Aponte. Uno de los nombres más sugerentes entre los mencionados es el de Rincón, un pintor de obra problemática a quien se documenta en Zaragoza ya en 1491 firmando un contrato de colaboración en exclusividad con Martín Bernat ${ }^{16}$. Se trata de uno de aquellos maestros quien, junto a Pedro de Aponte, fue objeto de elogio por parte de Jusepe Martínez ya en el siglo XVII, lo que no deja de ser significativo. Otro elemento de interés en su trayectoria es que fuese nombrado pintor del rey Fernando el Católico en 1514, lo que permite suponerle una cierta calidad ${ }^{17}$. Con anterioridad, Rincón aparece en Toledo en 1500 y 1503 trabajando al lado de Juan de Borgoña, y ello da que pensar ${ }^{18}$. En este sentido, son innegables los vínculos estilísticos y compositivos existentes entre el autor del retablo mayor de Bolea y Juan de Borgoña, por lo que Isabel Mateo propuso en su momento la posible identificación del Maestro de Bolea con Fernando del Rincón ${ }^{19}$. Ello ha sido nuevamente expuesto por Letizia Gaeta a la luz de la revisión que ha efectuado de la personalidad de Juan de Borgoña, de las tablas de Atri y el retablo boleano ${ }^{20}$. Sea como fuere, esta es la koiné artística que rodea los orígenes profesionales y el trabajo de Pedro de Aponte en Aragón, un entorno aún plagado de lagunas que en el futuro será necesario tratar de resolver.

15 Sobre esta cuestión, véase VELASCO, A. Some questions about the Flemish model in Aragonese painting (1440-1500). En: Alberto VELASCO y Francesc FITÉ, editores. Late Gothic Painting in the Crown of Aragon and the Hispanic Kingdoms, Leiden-Boston, Brill, 2018, pp. 121-123.

16 SERRANO SANZ, M. Documentos relativos a la pintura en Aragón durante el siglo XV. Revista de Archivos, Bibliotecas y Museos, 1914, XXXI, pp. 454-455, doc. IX. Sobre Rincón, véase RAMOS, F. J. Nuevos datos documentales sobre el pintor Hernando Rincón de Figueroa. Boletín del Museo e Instituto "Camón Aznar", 1996, LXVI, pp. 79-90 y SILVA MAROTO, P. Rincón de Figueroa, Fernando del. En: Museo del Prado [en línea] [consulta 8 agosto 2020]. Disponible en: http://www.museodelprado.es/enciclopedia/enciclopedia-on-line/voz/rincon-de-figueroa-fernando-del/.

17 MORTE, C. Fernando el Católico y las artes. En: Las artes en Aragón durante el reinado de Fernando el Católico (1479-1516). Zaragoza: Institución "Fernando el Católico", 1993, p. 173; YARZA, J. Política artística de Fernando el Católico. En: Ernest BELENGUER, coordinador. De la unión de coronas al Imperio de Carlos V. Madrid: Sociedad Estatal para la Conmemoración de los Centenarios de Felipe II y Carlos V, 2001, vol. III, pp. 27-28.

18 Se recogen ambas referencias en GAETA, ref. 12, p. 87

19 Alfonso E. PÉREZ SÁNCHEZ, editor. La pittura in Europa, La pittura spagnola. Milán: Electa, 1995, p. 227 (capítulo firmado por Isabel Mateo). Cfr. MORTE, ref. 9, pp. 47-78.

20 GAETA, ref. 12, pp. 86-87. 


\section{Trayectoria, obras documentadas y obras conservadas}

La documentación pone de manifiesto que Pedro de Aponte tuvo su taller instalado en Zaragoza, ciudad en la que aparece documentado por vez primera en $1502^{21}$. En 1503, como ya hemos visto, y junto al también pintor Pedro Despiota, contrató diversos trabajos para la iglesia de Bolea. En 1505 aparece residiendo en la calle Mayor de Zaragoza, en la parroquia de Santa Cruz, y ya tenía a su cargo algún aprendiz ${ }^{22}$. Dos años después contrató el retablo mayor de la capilla del Hospital de Nuestra Señora de la Esperanza de Huesca, documento del que se deduce que en ese momento trabajaba en alguna obra no concretada en la iglesia de Bolea, seguramente finalizando los trabajos contratados junto a Despiota en $1503^{23}$. Aún en 1507, pintaba unos armarios en la sacristía mayor del Pilar de Zaragoza ${ }^{24}$, y al año siguiente contrataba la pintura de las puertas del retablo mayor de la capilla del palacio de la Diputación de Zaragoza ${ }^{25}$. Otras noticias de ese año lo muestran colaborando con el pintor Antón de Aniano, por ejemplo, pintando un retablo dedicado a san Antonio de Padua con destino a Borja, por encargo de Juan Coloma ${ }^{26}$; o cobrando una parte del retablo contratado el año anterior en Huesca.

En 1509 lo encontramos implicado en la realización del retablo mayor de la iglesia de Azanuy, en la Franja, al que nos referiremos más adelante. En julio de 1510 Aponte cobraba el último pago por el retablo del hospital de Nuestra Señora de la Esperanza de Huesca, pero ese mismo año veía cómo fallecía su primera mujer, Catalina de Rupert, con la que había tenido dos hijas, Isabel y Jerónima ${ }^{27}$. En mayo del año siguiente contrató otra de sus obras conservadas, el retablo de Grañén ${ }^{28}$, que había sido iniciado en 1508 por el pintor Cristóbal de Cardeñosa (doc. 1507-1525), natural de Ávila, y que contó con mazonería - hoy desaparecida - de Gil de Brabante, el mismo entallador que realizó la obra escultórica del retablo mayor de Bolea y del de San Sebastián ${ }^{29}$. Hubo algún tipo de problema con la materialización del retablo de Grañén, ya que Cardeñosa solo llegó a realizar tres tablas - Oración en el Huerto, Prendimiento y Flagelación - que fueron visuradas y tasadas por Antón de Aniano y Enrique de Orliens en $1511^{30}$. De ahí que la obra se contratase de nuevo con Aponte. Es también a partir de 1511, y hasta 1515, cuando trabajó en el policromado de la predela del retablo mayor de la Basílica del Pilar, que había realizado en alabastro Damián Forment ${ }^{31}$. Todavía en 1511 sabemos que

21 GAY MOLINS, M. P. Aportación al estudio de las artes en Zaragoza: 1500-1525. En: Congreso Jerónimo Zurita. Su época y su escuela. Zaragoza: Institución "Fernando el Católico", 1986, pp. 433-434.

22 MORTE, ref. 4, p. 44.

23 ARCO, ref. 4, p. 69; MORTE, C. Documentos sobre pintores y pintura del siglo XVI en Aragón. I. Boletín del Museo e Instituto “Camón Aznar", 1987, XXX, doc. 19.

24 GAY, ref. 21, p. 433.

25 MORTE, ref. 23, p. 146 y ss.

26 MORTE, ref. 4, p. 23.

27 Se publica el testamento e inventario de sus bienes en MORTE, ref. 23, pp. 149-153.

28 ARCO, ref. 4, pp. 70-71; MORTE, ref. 23, pp. 153-154.

29 MORTE, ref. 4, pp. 17-18, doc. 1. Sobre el retablo de Grañén, véase también MORTE, ref. 4, pp. 70-78.

30 BALAGUER, F. Pintores zaragozanos, en protocolos notariales de Huesca. Seminario de Arte Aragonés, 1954, VI, pp. 86-88.

31 MORTE, C. El retablo mayor del Pilar. En: El retablo mayor de la Basílica de Nuestra Señora del Pilar. Zaragoza: Gobierno de Aragón, 1995, pp. 56-106. 
se asoció con el pintor Antón de Aniano para la posible realización de diversos retablos que habían de acometerse en la ciudad de Zaragoza ${ }^{32}$.

En 1512 firmó un compromiso de matrimonio con la que sería su segunda mujer, María de Arruego, aunque la unión no se materializó hasta 1520. Como ya hemos visto más arriba con el testimonio de uno de los hijos de la pareja, María era hija de Juan de Arruego, natural de Grañén, y de Violante de Ejea, de Fuentes. Hay que tener en cuenta que, el año anterior, Aponte había contratado el retablo de Grañén, lo que pudo permitirle conocer a la muchacha y su familia. Los Arruego, infanzones, entraron así en la vida del pintor, lo que se confirma con el hecho de que el notario Juan de Arruego, hermano de María y futuro cuñado de Aponte, fuese quien diese fe del contrato de colaboración con Antón de Aniano, de alguno de los documentos relacionados realización del retablo de Cintruénigo (1525), o la contratación de un aprendiz en 1526.

En 1513 debió finalizar el retablo de Grañén y al año siguiente se visuraban las puertas que había pintado para el retablo de la capilla del palacio de la Diputación del Reino en Zaragoza, realizado en escultura por Damián Forment ${ }^{33}$. Proseguían sus tareas, además, en la policromía del banco del retablo mayor del Pilar, igualmente realizado por dicho escultor, y realizaba la pintura del sepulcro de San Braulio en la misma basílica. En 1516 se vio involucrado en un pleito por un retablo dedicado a santa Isabel que había realizado por encargo de Ana Salmó, con destino a la iglesia de San Antón de Zaragoza ${ }^{34}$. Hacia 1517 debió colaborar en la pintura del primer proyecto de retablo mayor de la iglesia de la Magdalena de Zaragoza, una obra que, finalmente, acabó siendo realizada en escultura por Damián Forment ${ }^{35}$. En 1521 contrató un retablo dedicado a san Juan Bautista para la iglesia de Paniza $^{36}$, y al año siguiente policromaba veinte claves de bóveda en la cabecera de la basílica del Pilar, a la vez que realizaba otros encargos menores en el mismo templo. Estas tareas generaron un conflicto con los canónigos, pues se documenta un pleito en $1523^{37}$.

En este último año capitula uno de sus grandes retablos conservados, el de San Miguel de Ágreda, en Soria ${ }^{38}$, promovido por el protomédico de Adriano VI, García Fernández de Carrascón, obra con la que se inaugura la etapa final de producción del pintor. Las tareas debieron ocuparle hasta 1525, cuando inició otro de sus últimos retablos, igualmente conservado, el mayor de la iglesia de San Juan Bautista de Cintruénigo (Navarra). Todavía trabajaba en él en noviembre de 1529, pero no llegó a finalizarlo $^{39}$. En 1527 se documentan diversos problemas familiares con las hijas de su primer matrimonio, Isabel y Jerónima, año en que también sabemos de la realización de un retablo dedicado a santa Ana

32 ABIZANDA, M. Documentos para la historia artística y literaria de Aragón procedentes del archivo de protocolos de Zaragoza: Siglo XVI. Zaragoza: La Editorial, 1915-1917, vol. I, p. 25; ARCO, ref. 4, pp. 71-72; MORTE, ref. 4, pp. 48-49.

33 MORTE, ref. 23, pp. 163-164.

34 GAY, ref. 21, p. 433.

35 SALA, M. Estudios históricos y artísticos de Zaragoza. Zaragoza: Imprenta del Hospicio Provincial, 1933, p. 175; MORTE, ref. 4, pp. 50-51.

36 ABIZANDA, ref. 32, vol. II, pp. 39-42; ARCO, ref. 4, pp. 72-73.

37 MORTE, ref. 23, pp. 171-173.

38 MORTE, ref. 4, pp. 219-234; MORTE, ref. 4, pp. 39-59; MORTE, ref. 4, pp. 63-109.

39 Sobre el retablo de Cintruénigo, véase ABIZANDA, ref. 32, vol. II, pp. 35-36; ARCO, ref. 4, pp. 73-75; ANGULO, ref. 8, pp. $434-$ 444; MORTE, ref. 4, pp. 565-590; MORTE, ref. 4, pp. 11-78. 
para la cofradía con sede en la iglesia de Utebo ${ }^{40}$. También tenemos conocimiento de la realización en ese momento de un retablo para la iglesia de Calcena, encargo de Pedro Villalón, deán de Tudela y personaje muy próximo al papa Julio II, que era originario de dicha localidad. La obra fue visurada por el pintor Martín García ${ }^{41}$. Hacia 1528 debió iniciar el retablo mayor de Santa María de Olite, otra de sus obras navarras conservadas, pues en marzo de ese año ya aparece allí contratando por tres años a un aprendiz navarro, Juan de Hinojedo, que seguramente le ayudaría en la realización ${ }^{42}$. Simultaneó estos trabajos de Cintruénigo y Olite, obviamente con gran participación de oficiales de taller, con su actividad en Zaragoza, donde le documentamos en 1529 efectuando encargos menores para la Seo. Y así hasta 1530, en que la muerte le sorprendió en Olite sin poder finalizar alguno de los encargos pendientes. Había realizado testamento el 7 de abril. Después de su muerte, hubieron ciertas disputas económicas entre una de las hijas de su primer matrimonio, Jerónima, y su segunda mujer, María de Arruego ${ }^{43}$.

Analizando su trayectoria en global, vemos que a pesar de residir en Zaragoza, trabajó abundantemente en el área oscense, con obras realizadas en Huesca, Bolea, Grañén, Azanuy y Buil. Naturalmente, trabajó también en el entorno zaragozano (Zaragoza, Borja, Utebo y Paniza) y lo hizo puntualmente en tierras limítrofes castellanas (Ágreda, Soria). Al final de su trayectoria amplió su radio de acción profesional a Navarra con los retablos de Cintruénigo y Olite. Al igual que muchos artistas aragoneses del momento, se asoció con compañeros de oficio, como Antón de Aniano, y tejió redes de asistencia profesional, pues vemos a diversos artistas actuando como testigos en los documentos relacionados con sus encargos o, incluso, avalándole cuando es necesario, como trataremos al ocuparnos del retablo de Azanuy. No faltan tampoco las referencias a la entrada de aprendices en su obrador, un aspecto básico en la estructuración del taller y necesario para poder satisfacer encargos importantes con una cierta diligencia.

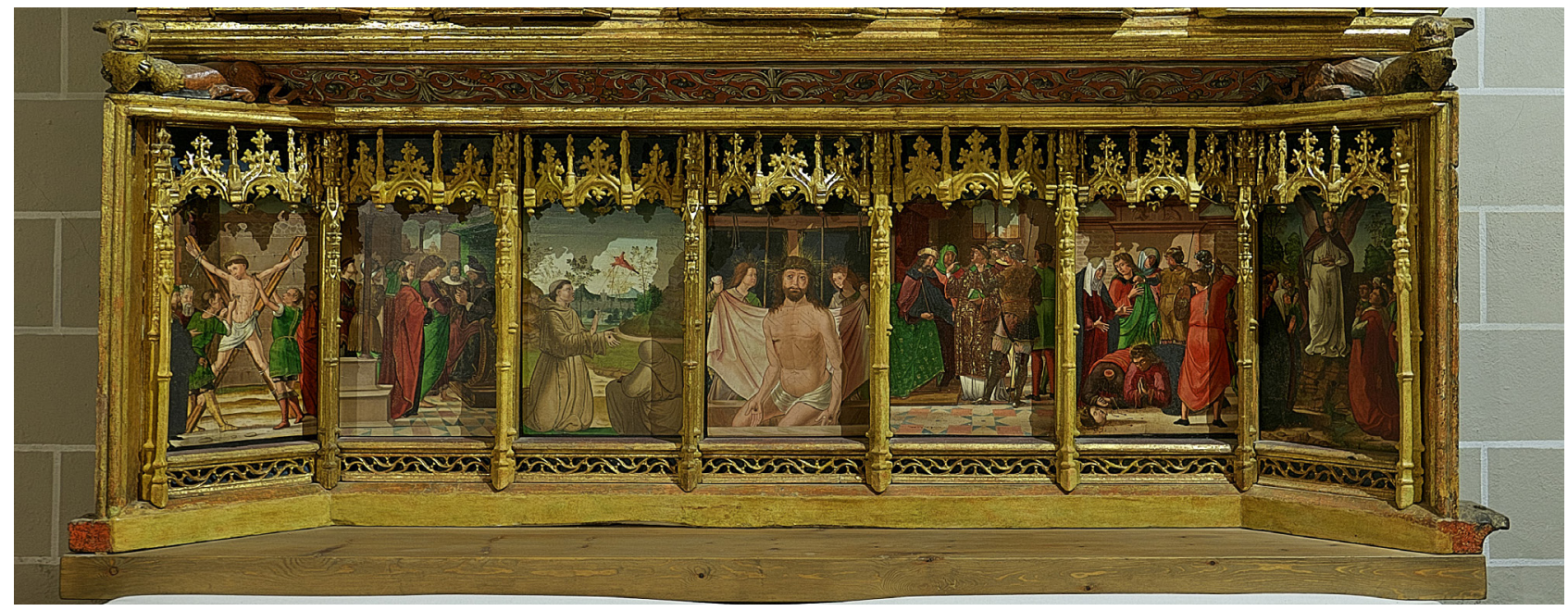

Fig. I: Pedro de Aponte. Predela del retablo de San Sebastián. Bolea, Colegiata de Santa María la Mayor. Foto: Wikimedia Commons (José Luis Filpo Cabana).

40 MORTE, ref. 4, p. 23; MORTE, ref. 4, pp. 54-55.

41 CRIADO, ref. 5, pp. 271-277; MORTE, ref. 4, p. 54.

42 ECHEVERRÍA, P. Policromía del Renacimiento en Navarra. Pamplona: Gobierno de Navarra, Departamento de Educación, Cultura y Deporte, 1990, p. 65. Sobre el retablo de Olite, véase MORTE, ref. 4, pp. 565-590; MORTE, ref. 4, pp. 13-123.

43 MORTE, ref. 4, p. 27. 
Como ya hemos ido apuntando, del conjunto de obras documentas de Pedro de Aponte han llegado hasta nuestros días algunas de ellas. La más antigua de todas es el Retablo de San Sebastián conservado en la iglesia de Bolea (Fig. 1), que formó parte del conjunto de encargos que los parroquianos le hicieron hacia 1503 a él y al también pintor Pedro Despiota. Se trata de un retablo que presenta escultura y mazonería en el cuerpo superior, seguramente obra de Gil de Brabante, que también tenía a su cargo la obra escultórica del retablo mayor del templo, mientras que los compartimentos pintados aparecen solamente en el bancal. La mano de Aponte se detecta en la mayoría de ellos, aunque especialmente en tres, el de San Sebastián ante Diocleciano, la Estigmatización de San Francisco y el Cristo Varón de Dolores. El Martirio de San Vicente es de peor calidad y seguramente fue realizado por Despiota, mientras que el resto, el Proceso de San Vicente, el Arresto de San Sebastián y el Ángel Guardián del Paraíso, pudieron ser el resultado del trabajo al alimón de ambos maestros. Ambos pintores tomaron préstamos en sus composiciones del retablo mayor realizado por el Maestro de Bolea, lo que demuestra que en ese momento la obra de este último ya se había concluido ${ }^{44}$.

Sabemos, por otro lado, que tanto él como Despiota colaboraron en la realización del retablo mayor de la misma iglesia, obra del Maestro de Bolea, aunque su implicación debió consistir en tareas secundarias como el policromado de la mazonería o la realización de las puertas, de las que se conservan algunos fragmentos con decoraciones de grutescos ${ }^{45}$. Tampoco se descarta que interviniesen en la pintura de los compartimentos bajo la supervisión del maestro principal, pero la detección de su mano en ellos hoy en día no es posible. En cualquier caso, se hace evidente que Aponte y Despiota entraron en contacto con uno de los pintores más interesantes del Primer Renacimiento en tierras aragonesas, y que conocieron de forma directa una de las obras más representativas en dicho territorio. No en vano Aponte copió y reinterpretó composiciones del retablo mayor de Bolea en varias de sus obras posteriores.

Una de las aportaciones del presente estudio es dar a conocer la única imagen conocida del retablo mayor de la iglesia de Azanuy (Fig. 11). Como ya hemos tenido ocasión de ver, se conocía documentación que demostraba que Aponte debía estar a punto de comenzar - o ya había iniciado-, el proyecto en 1509, por lo que dicha obra deviene la segunda más antigua conocida entre las documentadas del maestro. Desgraciadamente, el retablo fue parcialmente destruido durante la Guerra Civil española y únicamente hemos podido localizar las dos puertas, hoy conservadas en el Museo de Zaragoza, como más adelante tendremos ocasión de analizar al ocuparnos del conjunto monográficamente.

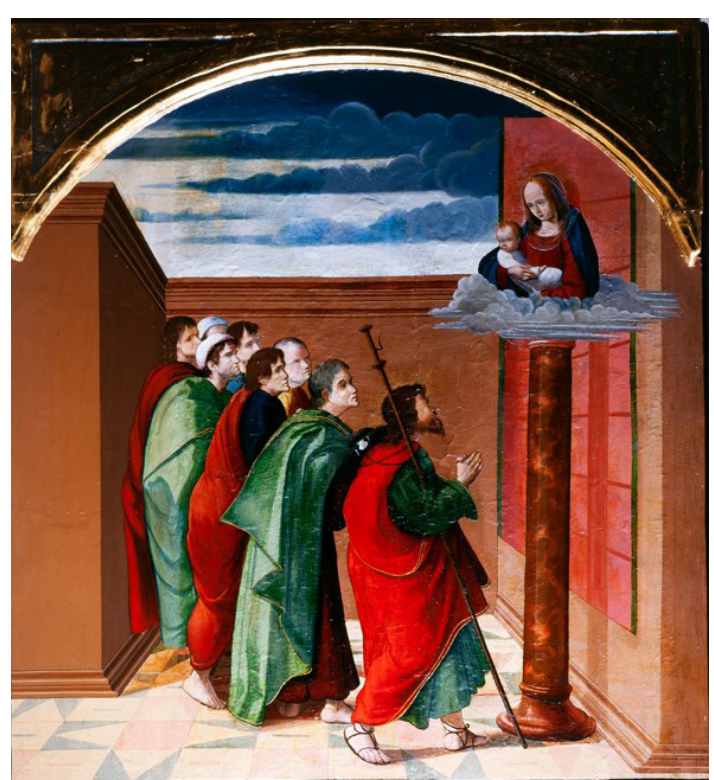

Fig. 2: Pedro de Aponte. Aparición de la Virgen del Pilar a Santiago y sus discípulos. Detalle del retablo mayor. Grañén, iglesia parroquial. Foto: Carmen Morte.

44 MORTE, ref. 4, pp. 96-98.

45 MORTE, ref. 4, fig. 16. 
Justo después de la finalización del conjunto de Azanuy, Aponte debió involucrarse en la realización del retablo mayor de la iglesia de Grañén (1511-1513), una obra que había dejado inconclusa el pintor Cristóbal de Cardeñosa. Dedicado a Santiago el Mayor y san Juan Evangelista, en la obra encontramos composiciones que Aponte repetirá posteriormente en los retablos de Olite y Cintruénigo. En Grañén, el pintor ya hace gala de ese interés por reforzar los valores expresivos de los rostros, priorizando esta cuestión por encima de la plasmación del modelo italianizante de belleza (Fig. 2). Esta tendencia se agudizará con el paso de los años y culminará en las obras de su período final. Desgraciadamente, el retablo sufrió una importante transformación a inicios del siglo XVII que comportó la desaparición de la mazonería y la substitución de algunos compartimentos, como el de la Asunción y el Calvario, además de la realización de repintes en otros que desvirtúan completamente el estilo original de Aponte.

El retablo de San Miguel de Ágreda (1523-1525) (Fig. 3) fue promovido por el doctor García Fernández de Carrascón (†1533), tesorero de la catedral de Tarazona, un personaje muy relevante que llegó

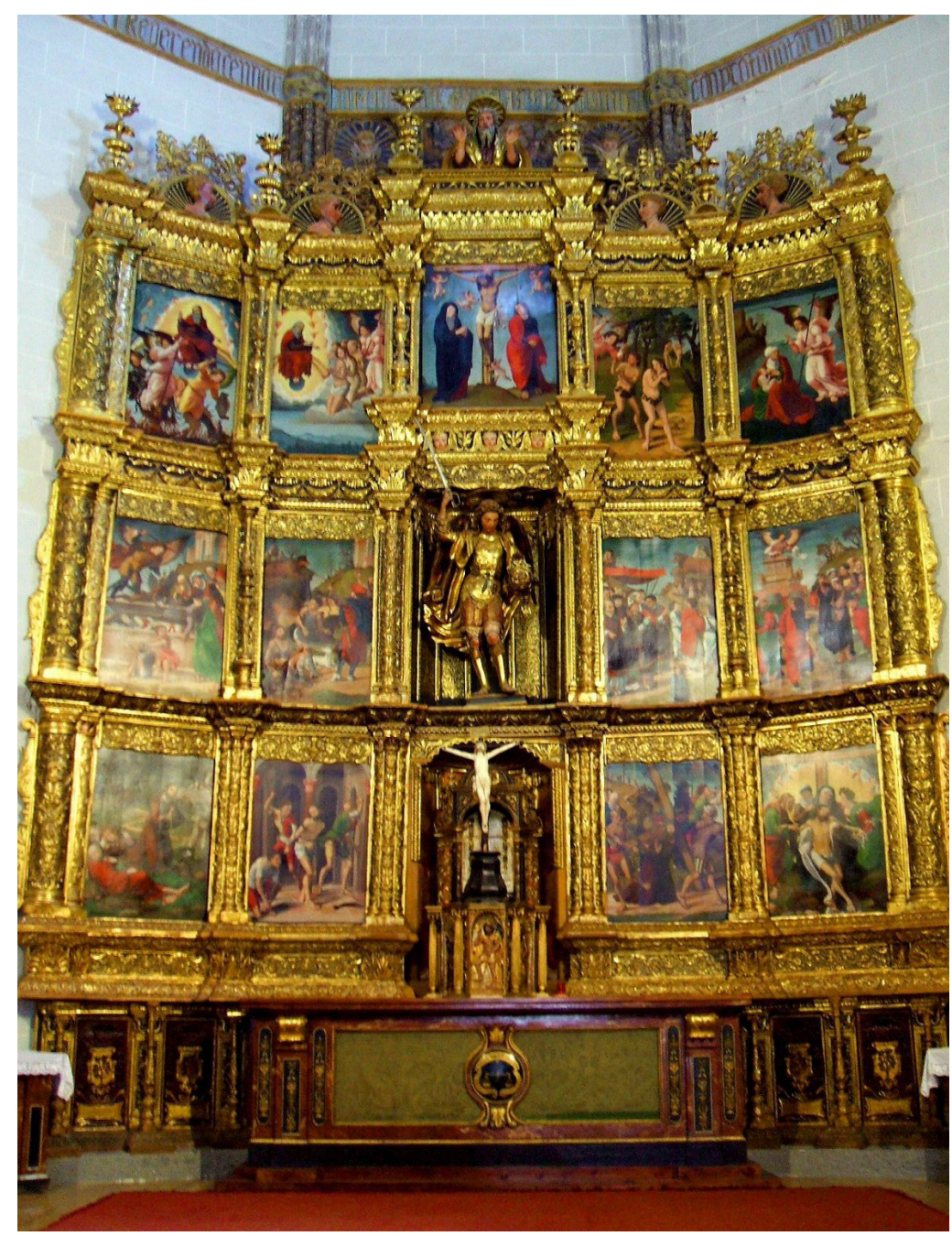

Fig. 3: Pedro de Aponte. Retablo de San Miguel. Ágreda, iglesia parroquial. Foto: Wikimedia Commons (Zarateman). a ser protomédico del papa Adrano $\mathrm{VI}^{46}$. Impulsó la renovación de la capilla mayor para destinarla a lugar de enterramiento personal, proceso que conllevó la contratación de Pedro de Aponte para la realización del retablo mayor. Con todo, al final se acabó reformando toda la fábrica del templo a expensas suyas. El retablo, que se contrató en junio de 1523 y debió finalizarse en 1525 , combina compartimentos pintados con mazonería dorada realizada por el entallador Antonio de Baños. Una bella imagen escultórica de san Miguel preside el conjunto y en cuanto a las escenas representadas, el ciclo desarrollado muestra en el nivel bajo temas de la Pasión y el Calvario en el ático. El resto están dedicadas al patrón del templo, además de una última escena dedicada a la Expulsión de Adán y Eva del Paraíso. Se trata

46 Sobre el personaje, véase MORTE, C. y MANRIQUE, M. E. El doctor García Fernández de Carrascón, protomédico de S. S. Adriano VI y protector de la iglesia parroquial de San Miguel de Agreda. En: El retablo de San Miguel de Ágreda (Soria). Historia y restauración. Soria: Caja Salamanca y Soria, 1997, pp. 15-35. 


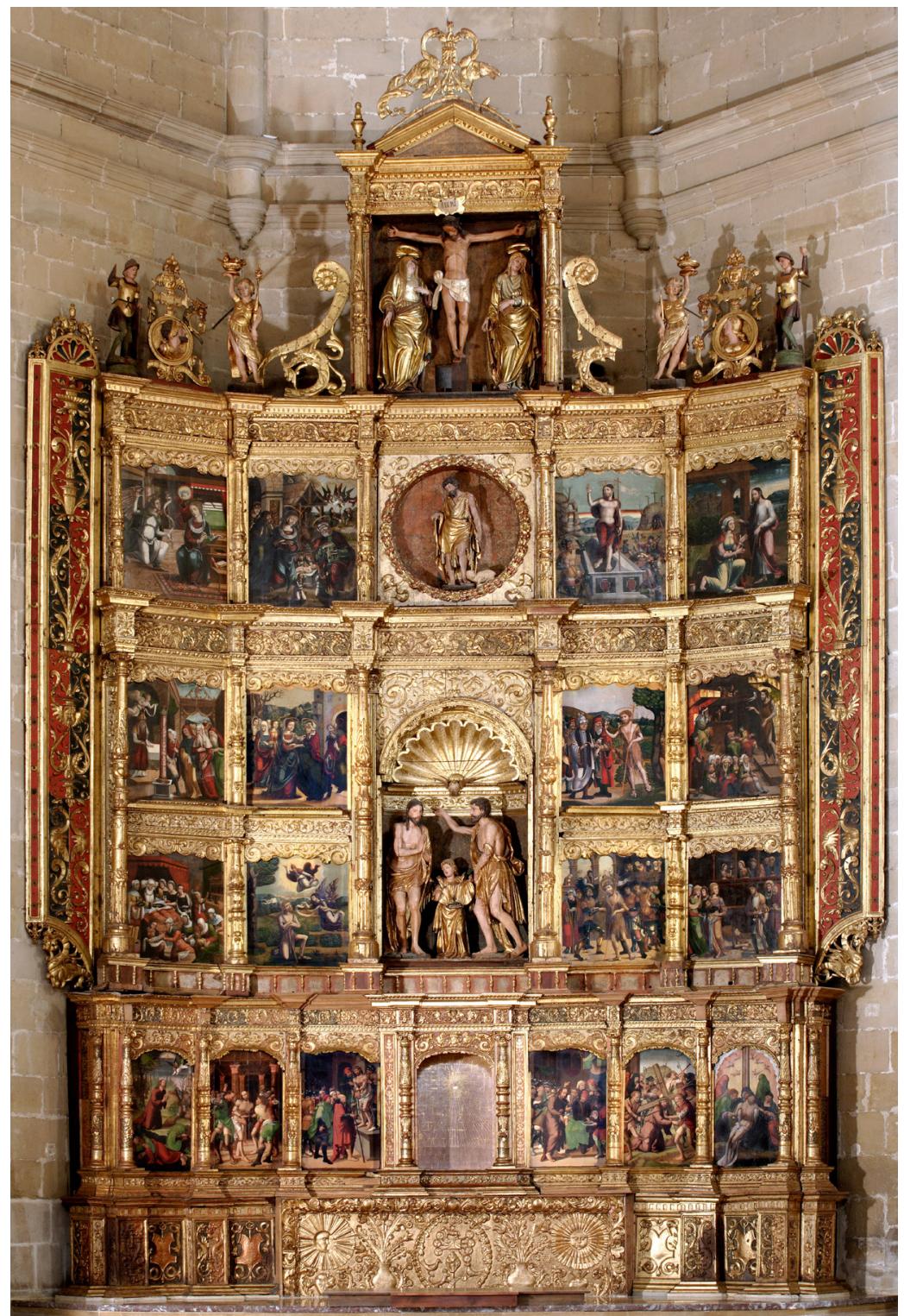

Fig. 4: Pedro de Aponte. Retablo de San Juan Bautista. Cintruénigo, iglesia parroquial. Foto: Carmen Morte.

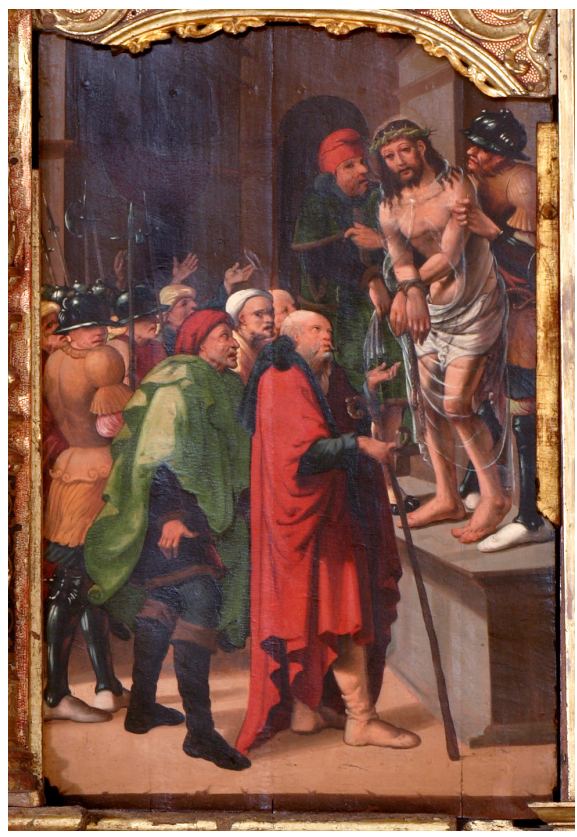

Fig. 5: Pedro de Aponte. Ecce Homo. Detalle del retablo mayor. Cintruénigo, iglesia parroquial.

Foto: Carmen Morte.

de uno de los conjuntos que mejor manifiesta el ascendente en Aponte del autor del retablo mayor de Bolea, de quien copió literalmente composiciones como la Oración en el Huerto.

Detrás de la intervención de Pedro de Aponte en el retablo mayor de la iglesia de San Juan Bautista de Cintruénigo (Fig. 4), en Navarra, seguramente se encuentra el mismo promotor del retablo de Ágreda, el doctor García Fernández de Carrascón, ya que era abad de la iglesia y tenía posesiones en la localidad. La obra debió iniciarse hacia 1525, ya que tenemos constancia que el pintor contrató la mazonería del retablo con Esteban de Obray, mazonero francés residente en Tudela, que posteriormente la subcontrató a otro mazonero del mismo origen, Guillén del Obispo. A Aponte solamente se le atribuyen las tablas del banco, dedicadas a la Pasión (Fig. 5), cuyo estilo se corresponde con el de sus últimas obras, esto es, los retablos de Ágreda y Olite, especialmente con este último. Los compartimentos del cuerpo superior, en cambio, se relacionan con el pintor Juan Giner, que residía en Cintruénigo ${ }^{47}$. Con todo, no se descarta que en el cuerpo del retablo pudiese intervenir una tercera mano.

El retablo mayor de Santa María de Olite (1528-1530) es la última de las obras documentadas de Aponte que conservamos, y se ha considerado como uno de los proyectos pictóricos más relevantes

47 La propuesta fue efectuada por ANGULO, D. La pintura del siglo XVI (Ars Hispaniae, vol. XII). Madrid: Plus Ultra, 1954, p. 75. Sobre Juan Giner, véase MORTE, ref. 4, pp. 26-28. 


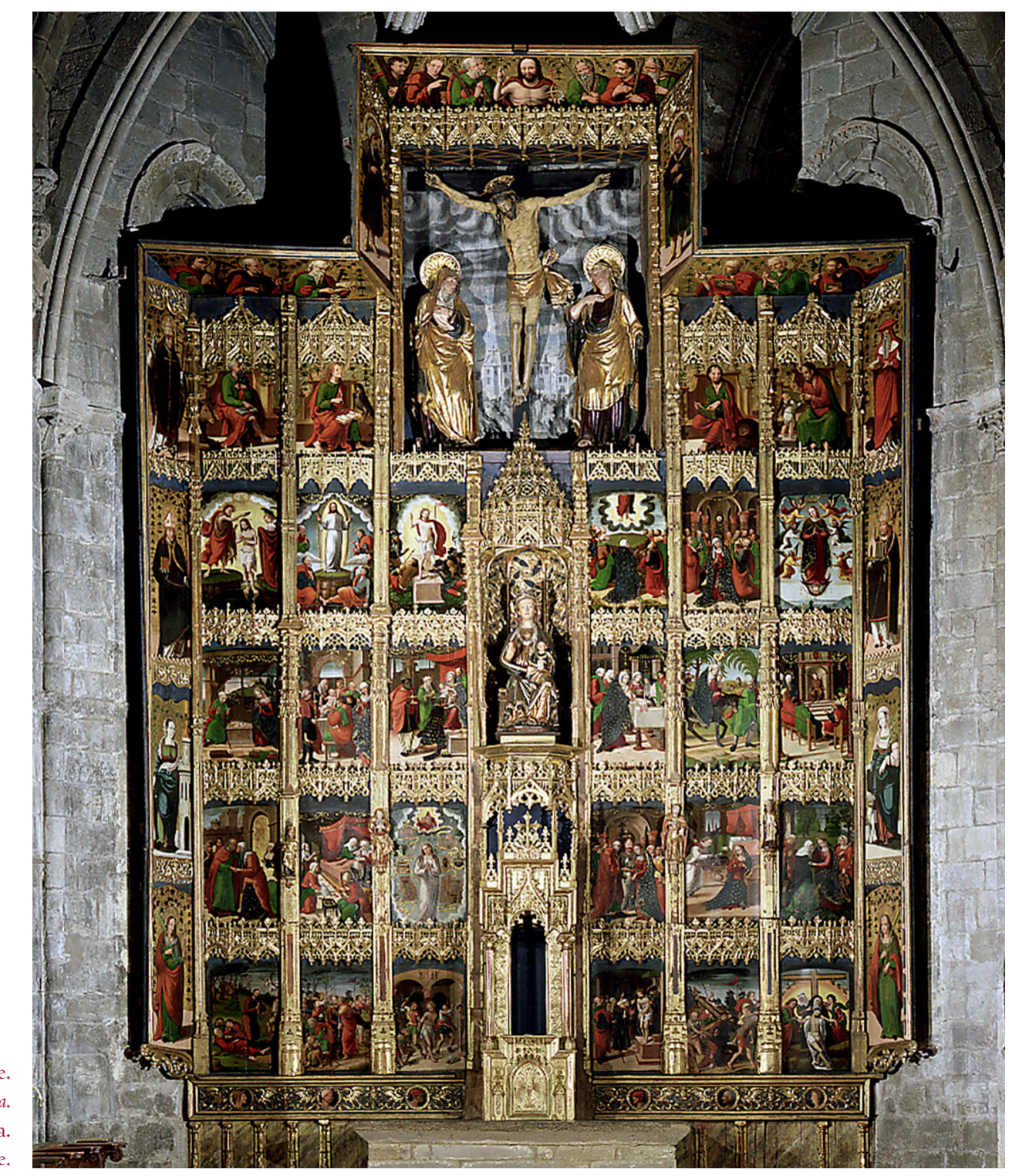

Fig. 6: Pedro de Apont

Retablo mayor de Santa María.

Olite, iglesia de Santa María.

Foto: Carmen Morte.

acometidos en tierras navarras en los primeros decenios del siglo XVI (Fig. 6). El cuerpo superior está dedicado a la Virgen mientras que el inferior presenta escenas de la Pasión. Al igual que los retablos de Ágreda y Cintruénigo, las composiciones y estilo son los

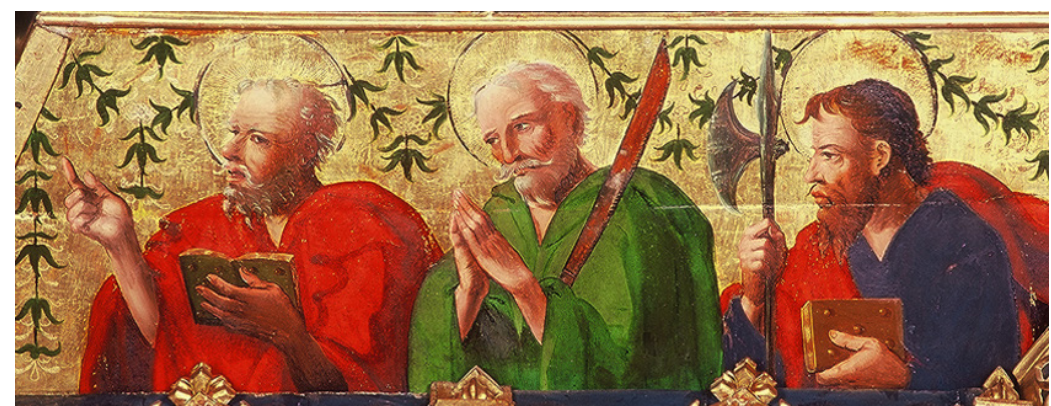

Fig. 7: Pedro de Aponte. Retablo mayor de Santa María. Detalles del guardapolvo. Olite, iglesia de Santa María. Foto: Carmen Morte. propios de los últimos años del pintor, en los que se hace muy evidente el uso de fuentes gráficas germánicas, especialmente Durero, y una expresividad muy característica y acusada que apuesta por el feísmo y los rostros de apariencia grotesca (Fig. 7).

Aparte de las obras conservadas y documentadas que hemos enumerado, han llegado hasta nuestros días unos pocos trabajos de Pedro de Aponte que se han incluído en su catálogo a partir de la atribución estilística. Es el caso de una Virgen con el Niño de colección particular barcelonesa dada a 
conocer por Angulo en 1954, quien la atribuyó al por entonces denominado Maestro de Ágreda ${ }^{48}$. Es una obra de pequeñas dimensiones $(49,5$ x 37,4 cm) seguramente destinada a la devoción privada, lo que le confiere un interés añadido. Se trata de una tabla sútil y de delicada ejecución, que presenta una inscripción en la parte superior (AVE - GRACIA $\cdot$ PLENA $\cdot$ BO $\cdot$ MINUS) y dos delicadas guirnaldas verticales de campanillas florales en los laterales. Esas mismas campanillas aparecen rodeando a los personajes del guardapolvo del retablo de Olite y también en la parte superior de buena parte de los compartimentos, detalle que merece ser puesto de relieve para reforzar la atribución. El tejido que cubre la repisa de primer término muestra un escudo heráldico que Jaume Barrachina identificó con la estirpe de los de la Caballería ${ }^{49}$, una familia de judíos conversos de gran relevancia en Aragón ${ }^{50}$. Por cronología, la tabla pudo ser realizada para Sancho de la Caballería, un personaje que pudo cruzarse en la trayectoria de Pedro de Aponte en otra ocasión, como prueba el contrato de sociedad subscrito en 1511 por nuestro pintor y Antón de Aniano para la posible realización de diferentes obras, una de las cuales era un retablo encargado por Sancho de la Caballería ${ }^{51}$.

Entre las atribuciones debemos mencionar también tres compartimentos de retablo conservados hasta 1936 en la iglesia de San Martín de la localidad de Santa María de Buil. Mostraban a San Martín partiendo la capa con un pobre (Fig. 8), San Antonio Abad (Fig. 9) y San Miguel abatiendo al maligno (Fig. 10) ${ }^{52}$, y fueron seguramente destruidos durante la Guerra Civil española ${ }^{53}$. Debieron formar parte del retablo mayor que, a la vista de la arquitectura románica y la cabecera tripartita del templo, fue de dimensiones mucho más reducidas que algunas de las obras hasta ahora analizadas. El San Martín respondía a un modelo iconográfico ampliamente difundido en tierras aragonesas desde los tiempos de Blasco de Grañén y, especialmente, durante la segunda mitad del siglo $\mathrm{XV}^{54}$, mientras que el San Miguel combinaba las dos facetas del personaje, la de psicopompo evaluador de almas, y la Miles Christi que combate contra el diablo. Se aprecian claramente en la tabla los potentes reflejos en la armadura del santo, que ponen de manifiesto una cierta pericia por parte del pintor y que remiten a la tradición flamenca en la que se formó. En cuanto al San Antonio Abad, responde también a modelos ampliamente difundidos en tierras aragonesas desde época gótica.

Estilísticamente, Post vio en las tablas de Buil múltiples paralelos con los compartimentos del retablo de Grañén, señalando que se llega a repetir la caracterización de algunos personajes, como vemos al comparar el rostro del San Antonio Abad con el de Simón de Cyrene en el Camino del Calvario de

48 ÁNGULO, ref. 47, p. 75. Cfr. POST, Ch. R. The Schools of Aragon and Navarre in the Early Renaissance (A History of Spanish Painting, vol. XIII). Cambridge (Massachusetts): Harvard University Press, 1966, pp. 72-73, fig. 25.

49 BARRACHINA, ref. 5, pp. 292-295.

50 A esta familia perteneció Gonzalo de la Caballería, el promotor del retablo que Pere Joan y Pascual Ortoneda realizaron para la capilla de las Casas del Puente, la casa de la ciudad de Zaragoza. Sobre este retablo, no conservado, véase VELASCO, A. Para que sus deliberaciones y consejos no vayan herrados sino acertados. Gonzalo de la Caballería y el retablo de la capilla del Concejo de Zaragoza (1443). Tvriaso, 2014-2015, 22, pp. 295-340, con mención a la obra de Aponte que nos ocupa (pp. 321-322, nota 83).

51 MORTE, ref. 4, p. 48.

52 Se dieron a conocer en ARCO, R. Catálogo Monumental de España: Huesca. Madrid: Instituto Diego Velázquez (CSIC), 1942 , vol. I, pp. 280-281, vol. II, figs. 700-702. La atribución de los tres compartimentos a Aponte la debemos a POST, ref. 48, p. 86.

53 Conocemos las tablas gracias a las fotografías conservadas en el Institut Amatller d'Art Hispànic de Barcelona.

54 Véase, por ejemplo, un compartimento de retablo de Tomás Giner que muestra una composición muy similar en VELASCO, A. Spanish Paintings from 14th to 16th Centuries. Madrid-Londres: Caylus, Sam Fogg, 2019, pp. 94-101. 


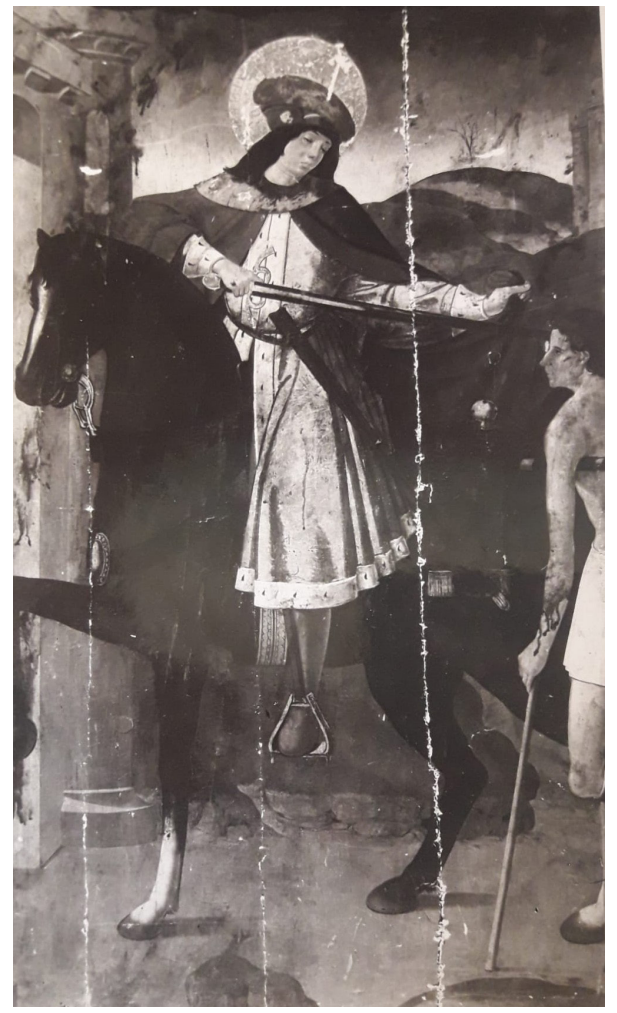

Fig. 8: Pedro de Aponte. San Martín partiendo la capa con un pobre. Santa María de Buil, iglesia de San Martín. Foto: Institut Amatller d'Art HispànicArxiu Mas.

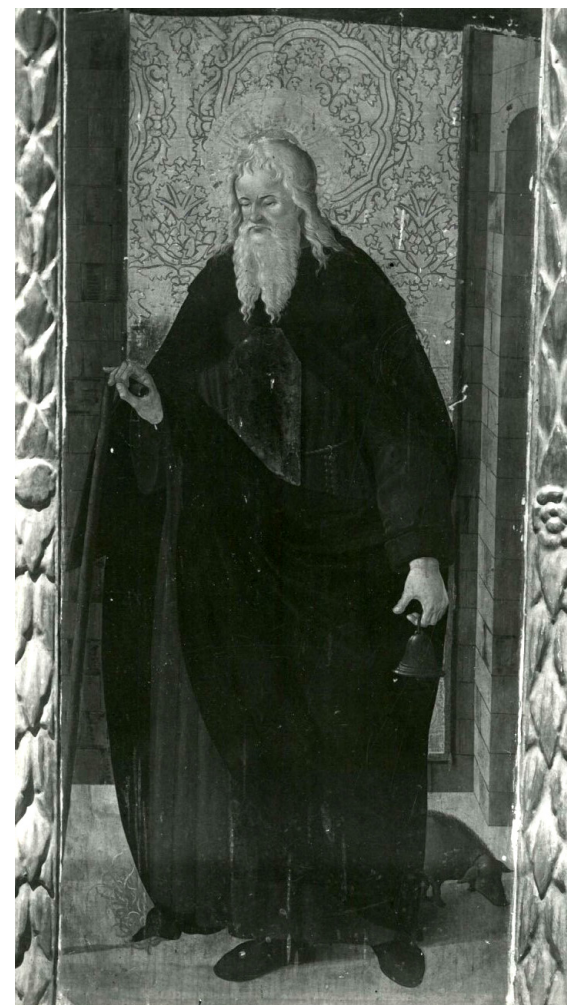

Fig. 9: Pedro de Aponte. San Antonio Abad. Santa María de Buil, iglesia de San Martín. Foto: Institut Amatller d'Art Hispànic-Arxiu Mas.

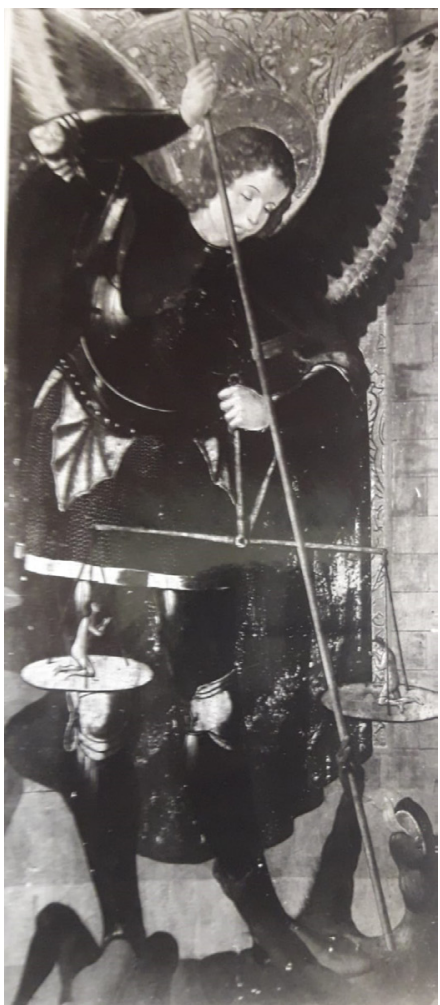

Fig. I0: Pedro de Aponte. San Miguel abatiendo al maligno. Santa María de Buil, iglesia de San Martín. Foto: Institut Amatller d'Art Hispànic-Arxiu Mas.

Grañén ${ }^{55}$. Por otro lado, el paño de honor y el murete de sillares que aparece en las tablas de San Antonio Abad y San Miguel son muy parecidos a los que encontramos en otras dos tablas que, de momento, solamente mencionaremos. Se trata, en primer lugar, de un compartimento de retablo con Santiago y una donante conservado hace años en manos privadas, hoy en el Museu Nacional de Arte Antiga de Lisboa (Fig. 18). La obra es interesante porque puede ponerse en relación con una segunda tabla hasta hoy inédita que perteneció al mismo retablo, hoy conservada en colección particular, y que muestra a Santa Elena y el Emperador Constantino. Volveremos sobre ambas más adelante.

Finalmente, en la actualidad se atribuye al pintor alguna obra con más dudas, como la pintura de la caja sepulcral de la infanta María de Aragón, hija de Jaime I el Conquistador y Violante de Hungría, procedente de la capilla mayor de la Seo de Zaragoza y hoy conservada en el Museo de Tapices de la catedral ${ }^{56}$. Asimismo, históricamente, autores como Ricardo del Arco o Post le habían atribuido otros trabajos, pero los estudios desarrollados en los últimos decenios han descartado su inclusión en el catálogo del pintor debido a diferentes motivos, ya sea por evidentes razones estilísticas, o bien porque se trata de obras conservadas antiguamente en colecciones particulares de las que nunca se han llegado a publicar fotografías ${ }^{57}$.

55 POST, ref. 48, p. 86.

56 Sobre esta última obra, véase MORTE, C. Los arzobispos de la Casa Real: Don Alonso, Don Juan y Don Hernando de Aragón (1478-1575). En: La Seo de Zaragoza. Zaragoza: Diputación General de Aragón, 1998, p. 214; OLMO, A. ¿Pedro de Aponte? Arqueta de la infanta María. En: Carmen MORTE, directora. El esplendor del Renacimiento en Aragón. Zaragoza: Gobierno de Aragón, Museo de Bellas Artes de Bilbao, Generalitat Valenciana, 2009, p. 173.

57 ARCO, ref. 4, pp. 59-77; POST, ref. 48, pp. 48-91. Véase una recopilación de las obras atribuidas en algún momento a Aponte en NAVAL, ref. 5, passim. 


\section{Atando cabos: el retablo mayor de Azanuy}

Hace ya algunos años, a partir de un protocolo del notario de Zaragoza Pedro Garín, Carmen Morte dio a conocer brevemente que en 1509 Pedro de Aponte trabajaba en la obra de un retablo para la iglesia de Azanuy (Sanui, en catalán), localidad ubicada en la actual comarca de la Litera, en la Franja ${ }^{58}$. Los documentos relacionados con este encargo son bastante parcos en información, pero lo cierto es que tienen interés más allá del hecho en sí que certifican. En este sentido, el 19 de agosto de 1509, Juan Ximénez, fustero ${ }^{59}$, Miguel Gil de Palomar, pintor, y Juan Chamorro, también pintor, todos ellos vecinos de Zaragoza, actuaron como fiadores y avaladores de "Qualesquiere obras por el dicho mestre Pedro Pont faze" en Azanuy (doc. 1). El instrumento notarial parece revelar que el trabajo del pintor en la localidad se había iniciado ya, pues se habla de las obras que el pintor "faze", en presente. En el mismo folio del manual notarial, justo a continuación, el sastre de Zaragoza Juan de Pelayo firmaba un documento similar al anterior. Y lo mismo puede afirmarse de Francisco Pérez, corredor, y de Gabriel Álvarez, bordador de Zaragoza ${ }^{60}$, que también avalaron el trabajo de Aponte. Unos folios más adelante, un documento de 31 de agosto recoge que la esposa del pintor, Catalina de Rupert, actuó de forma similar declarando que los trabajos consistían en "la obra de un retablo que el dicho su marido tiene de fazer en el lugar de Azanuy". En este segundo instrumento vuelve a aparecer el pintor Juan Chamorro, esta vez firmando como testigo (doc. 2).

Como vemos, los documentos en cuestión nos hablan sobre el proceso de recogida de avales económicos que el pintor llevó a cabo para poder acometer la realización de un retablo que, según se deduce, debió ser importante. Es evidente que una obra secundaria o un encargo de poca relevancia no hubiera requerido de tantas obligaciones y fianzas como las que se describen en los documentos. Podría concluirse, así las cosas, que Pedro de Aponte trabajaba en 1509 en Azanuy en algo con enjundia, seguramente la obra del retablo mayor.

Según rezan los documentos apuntados, el pintor contó con el apoyo de compañeros de oficio a los que conocemos por otras referencias relacionadas con encargos artísticos. Nos referimos a los pintores Miguel Gil de Palomar y Juan Chamorro. Sobre el primero, sabemos que en 1511 fue el encargado de policromar el desaparecido sepulcro de Juan de Lanuza, virrey de Sicilia y Justicia de Aragón, que había esculpido Gil Morlanes el Viejo hacia 1508 para la capilla familiar en Nuestra Señora del

58 Protocolo Pedro Garín, Archivo Histórico de Protocolos de Zaragoza (citaré AHPZ), año 1509, fols. 127v y 133v. Referenciado en MORTE, ref. 4, p. 67; MORTE, ref. 4, p. 23; MORTE, ref. 4, p. 46.

59 Ximénez es un carpintero conocido por otros documentos. Por ejemplo, sabemos que a partir de 1512 realizó junto al imaginero Juan Salazar la talla de la sillería del coro del monasterio de Santa Engracia de Zaragoza. Véase MORTE, ref. 17, p. 192 , doc. 16. Novedades documentales sobre el proyecto en CRIADO, J. La fábrica del monasterio jerónimo de Santa Engracia de Zaragoza, $1492-$ 1517. Artigrama, 1998, 13, p. 269.

60 Gabriel Álvarez (ca. 1509-1529) es el fundador de una importante dinastía de bordadores zaragozanos. Estuvo especialmente vinculado a la sacristía de la basílica del Pilar, donde tuvo especial cuidado de la reparación de los ornamentos hasta 1529, fecha aproximada de su fallecimiento. Sabemos que también trabajó para la Seo de Zaragoza, la catedral de Jaca (1514) o la parroquial de Cariñena (1518). Sobre el personaje, véase ÁGREDA, A. M. Los ornamentos en las iglesias zaragozanas. Siglos XVI-XVIII. Aportaciones al estudio de los talleres de bordado y de las artes textiles en Aragón en la Edad Moderna. Zaragoza: Institución "Fernando el Católico", 2001, pp. 439-440 y ÁGREDA, A. M. Los ornamentos de la Seo de Zaragoza en el siglo XVI: el funcionamiento de la sacristía. En: María Isabel ÁLVARO y otros, coordinadores. Estudios de historia del arte: libro homenaje a Gonzalo M. Borrás Gualis. Zaragoza: Institución "Fernando el Católico", 2013, pp. 47-59. 
Pilar ${ }^{61}$. En 1517 Palomar consta como mayordomo de la Cofradía de San Lucas de los Pintores de Zaragoza coincidiendo con el proceso de reforma de sus ordenaciones ${ }^{62}$. También intervino entre 1518 y 1524 en el policromado del retablo mayor de la iglesia de San Pablo de Zaragoza, obra escultórica de Damián Forment ${ }^{63}$. Debe señalarse que la documentación relacionada con el retablo de Azanuy no es la única en la que Gil de Palomar aparece involucrado en un encargo realizado por Pedro de Aponte. Así, en 1514, junto al mencionado Forment y al pintor Jaime Romero, visuraron las puertas que Aponte pintó para el retablo escultórico de la capilla del palacio de la Diputación del Reino en Zaragoza, obra del mencionado Forment ${ }^{64}$.

En cuanto al castellano Juan Chamorro, conocemos también algunas referencias sobre su trayectoria profesional que nos lo muestran activo entre 1502 y $1537^{65}$. Llegó a Zaragoza seguramente procedente de Toledo, y se le documenta en 1508 contratando la policromía del claustro chico del monasterio de Santa Engracia de Zaragoza ${ }^{66}$. Al igual que Gil de Palomar, Chamorro consta en 1517 como miembro de la cofradía de pintores de San $\operatorname{Lucas}^{67}$, y también colaboró entre 1520-1521 en la policromía del retablo de San Pablo de Zaragoza ${ }^{68}$. Todavía en ese lapso de dos años, aparece realizando tareas de policromía escultórica en la Seo de Zaragoza ${ }^{69}$. En 1525 capituló el retablo mayor del convento del Carmen de Calatayud ${ }^{70}$, y cinco años después hizo lo propio con un retablo para El Castellar ${ }^{71}$. En 1531 visuraba la pintura del retablo de Santa Engracia de Tauste, realizada por Antón Ortín ${ }^{72}$. Al igual que en el caso de Gil de Palomar, los documentos relativos al retablo de Azanuy no son los únicos en los que Chamorro aparece al lado de Pedro de Aponte. Así, en 1511, junto al escultor Juan Salazar, firmó como testigo en el mencionado contrato de sociedad que Aponte subscribió con el también pintor Antón de Aniano para la realización de diversas obras, e hizo lo mismo diez años después

61 ABIZANDA, ref. 32, vol. II, pp. 80-83.

62 ABIZANDA, ref. 32, vol. I, p. 3.

63 MORTE, C. y otros. El Retablo Mayor de la Iglesia Parroquial de San Pablo de Zaragoza. Restauración 2006. Madrid: Ministerio de Cultura, 2007.

64 MORTE, ref. 23, pp. 163-164.

65 El primer documento sobre la presencia de Chamorro en Zaragoza se da a conocer en CRIADO, J. Las artes plásticas del Primer Renacimiento en Tarazona (Zaragoza). El tránsito del moderno al romano. Tvriaso, 1992, 10 (2), p. 397.

66 MORTE, C. Introducción. En: Aragón y la Pintura del Renacimiento. Zaragoza: Museo e Instituto “Camón Aznar”, 1990 , p. 18 y 34; CRIADO, J. y IBÁÑEZ, J. La introducción del ornato al romano en el Primer Renacimiento aragonés. Las decoraciones pictóricas. Artigrama, 2003, 18, p. 333.

67 ABIZANDA, ref. 32, vol. I, pp. 4-6.

68 ABIZANDA, ref. 32, vol. I, p. 86.

69 IBÁÑEZ, J. Los cimborrios aragoneses del siglo XVI. Tarazona: Centro de Estudios Turiasonenses, 2006, p. 14.

70 ACERETE, J. M. Estudio documental de las artes en la Comunidad de Calatayud en el siglo XVI. Calatayud: Centro de Estudios Bilbilitanos, 2001, p. 413; BRUÑÉN, A. I. y SENAC, M. B. Retablo mayor del Convento del Carmen Calzado de Calatayud. En: $I V$ Encuentro de Estudios Bilbilitanos. Actas I. Calatayud: Centro de Estudios Bilbilitanos, Institución "Fernando el Católico", 1997, pp. 315-320.

71 PÉREZ, P. El pintor Juan Chamorro en El Castellar. Vida Alagonesa, 3, 1999.

72 MORTE, C. Del Gótico al Renacimiento en los retablos de pintura aragonesa durante el reinado de Fernando el Católico. En: María del Carmen LACARRA, coordinadora. La pintura gótica durante el siglo XV en tierras de Aragón y en otros territorios peninsulares. Zaragoza: Institución "Fernando el Católico", 2007, p. 345; MORTE, C. y CASTILLO, M. (2012): "Estudio histórico-artístico". En: Carmen MORTE y Margarita CASTILLO, coordinadoras. El retablo mayor renacentista de Tauste. Zaragoza: Institución "Fernando el Católico", 2012, p. 94. 


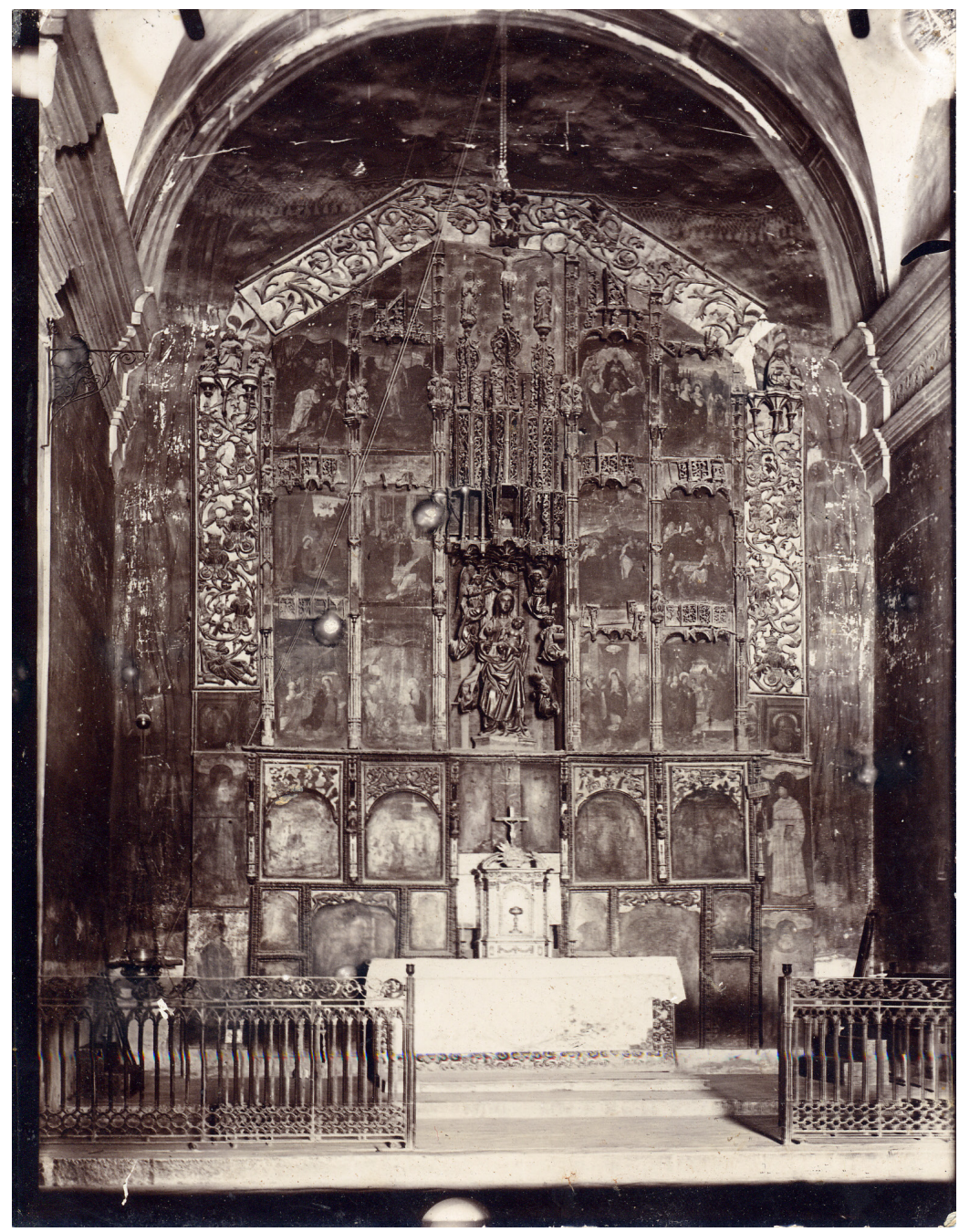

Fig. II: Pedro de Aponte. Retablo mayor de Santa María. Azanuy, iglesia parroquial. Foto: Archivo Barón de Valdeolivos de Fonz. cuando Aponte contrató en 1521 el también citado retablo de Paniza. Todo ello seguramente indica que la relación profesional y personal entre ambos era estrecha.

Volviendo a los documentos sobre el trabajo de Pedro de Aponte en Azanuy, desde que Morte dio a conocer la referencia de los mismos, nadie más se había ocupado de la cuestión. En fecha reciente, con todo, hemos podido cruzar estas noticias con la existencia en el Archivo Barón de Valdeolivos de Fonz (Huesca), formando parte del fondo de Francisco de Otal y Valonga, de un cliché fotográfico de vidrio de 1928 que muestra el retablo ma-

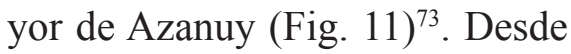
que dimos a conocer la existencia de la fotografía en cuestión habíamos intentado esclarecer, sin éxito, la autoría del retablo ${ }^{74}$. La ima-

gen muestra un retablo de impresionantes dimensiones que combinaba pintura y obra de mazonería, y que ocupaba el altar mayor de la iglesia de la Asunción. Sin duda, fue un trabajo realizado durante los primeros años del siglo XVI. Ello hace inevitable la asociación con las noticias documentales que nos hablan sobre la actividad de Aponte en Azanuy hacia 1509. Por tanto, gracias al cruce de informaciones y al análisis estilístico, podemos certificar que los compartimentos pintados del retablo mayor de Azanuy fueron realizados por Pedro de Aponte, por lo que debe añadirse este conjunto a las obras documentadas y conocidas del pintor, aunque solo sea gráficamente.

La fotografía y los documentos firmados ante el notario Pedro Garín se habían convertido en dos de los escasos testimonios que nos quedaban de la obra, como más adelante explicaremos. Dos muestras más de la existencia del retablo en el altar mayor de la parroquia eran las descripciones que

73 Documentación personal y funcional, Archivo Barón de Valdeolivos, Casa Ric, Francisco de Otal y Valonga, Actividades intelectuales, Dosieres genealógicos y heráldicos, ref. 00129/0004. Fue en el año 2000 cuando Enrique Badia, entonces responsable del archivo, y Josep Manuel Martínez París, investigador de la Universitat de Lleida, nos informaron amablemente sobre la existencia de la fotografía. Debemos señalar, además, que en el Archivo Histórico Provincial de Huesca se conserva un positivo en papel de dicho cliché (Fondo Mariano de Pano y Ruata, Archivo Histórico Provincial de Huesca, ref. ES/AHPHU - F/00120/0028).

74 Publicamos la fotografía en VELASCO, A. Pintura tardogòtica a l'Aragó i Catalunya: Pere Garcia de Benavarri. Tesis doctoral inédita, Universitat de Lleida, 2015, vol. I, 215 y vol. II, fig. 81. 
realizaron un par de eruditos. El primero de ellos es Sebastián de Mercadal, quien en 1873 se refería a la obra en los siguientes términos:

“La única escultura, que adorna el altar, reproduce con sus estatuas el misterio de la Asunción de Maria á los cielos. Un magnífico doselete gótico corona á esta imagen [...] A uno y otro lado de esta imagen varios cuadros de paleta gótica adornan el altar y le dividen en tres cuerpos, en donde el pueblo fiel puede en 16 cuadros leer en toda lengua los misterios mas principales de nuestra Redención, en la que tomó parte tan activa la Madre de Dios"75.

Más parca y lacónica es, en cambio, la que nos dejó Ricardo del Arco (1916): "Retablos góticos importantes los hay asimismo: [. . . ] en Azanuy, el mayor, espléndido"76. Y hasta ahí. Nada más se sabía del retablo, de su autoría y fecha de realización, ni de su suerte final. Sobre esta última cuestión, el retablo hoy ya no preside el presbiterio de la iglesia parroquial. Lo lógico sería pensar que fue destruido durante la Guerra Civil española, y más si hacemos caso de lo que se afirma en un documento de 1955 redactado por Mn. Eusebi Vidal Bergé (1880-1958) conservado en el Arxiu Diocesà de Lleida. Sobre la iglesia de Azanuy, Vidal afirmó que "El órgano, retablo, tablas, tapices, imágenes, vasos sagrados, campanas, ornamentos, fueron destruidos, robados o quemados". Ampliando la información sobre el retablo apuntó que "[...] era gótico del siglo XV, con marco platermo [sic], valorado por técnicos en 75.000 pesetas" ${ }^{\prime 77}$. Sin embargo, y como veremos más adelante, existen motivos suficientes para sospechar que no todos los compartimentos fueron destruidos, ya que en el Museo de Zaragoza se conservan las puertas con las representaciones de san Pedro y san Pablo.

Una cuestión que llama poderosamente la atención es que Chandler Rathfon Post (1881-1959), gran especialista en la pintura medieval hispana y profesor de la Universidad de Harvard, no mencionase el retablo mayor de Azanuy en ninguno de los volúmenes de su monumental A History of Spanish Painting. Y lo es porque Post visitó el templo en persona en verano de 1932, según el mismo reconoció ${ }^{78}$. Son conocidas las diferentes excursiones científicas de Post a España y todo el trabajo de campo que efectuó en centenares de iglesias, muchas de ellas en territorio aragonés, con las que fue nutriendo progresivamente los volúmenes de la historia de la pintura española que iba publicando. Su exhaustividad es sobradamente conocida, dando a conocer retablos y retablos, tablas y más tablas, ya se conservasen in situ, en museos de todo el mundo o en colecciones particulares. Por ello, es realmente sorprendente que un retablo de la magnitud y relevancia del de Azanuy no quedase plasmado

75 MERCADAL, S. España Mariana, o sea reseña histórica y estadística. . Provincia de Huesca, Partidos de Fraga y Tamarite. Lleida: Imprenta de Francisco Carruez, 1873, pp. 105-106.

76 ARCO, R. del. La pintura de primitivos en el Alto Aragón (conclusión). Arte Español, 1916, III (1), p. 21. Años después, del Arco se refirió en términos similares: "de espléndida factura, pertenece al comienzo del siglo XVI" (ARCO, ref. 52, vol. I, 413).

77 Procés 1952, Arxiu Diocesà de Lleida, Eusebio Vidal, Documentació sobre la Guerra Civil Española 1936-1939. Publicamos parcialmente el documento en VELASCO, A. y BERLABÉ, C. Violència i estralls contra el patrimoni artístic lleidatà durant la guerra civil espanyola. En: Oriol Dueñas y Josep Lluís Martín, editores. La Guerra Civil al Territori. Lleida, Tarragona i Girona. Barcelona: Generalitat de Catalunya, 2017, pp. 171-245, con mención explícita a las informaciones sobre Azanuy en la p. 219.

78 POST, Ch. R. The Catalan School in the Late Middle Ages (A History of Spanish Painting, vol. VII). Cambridge (Massachusetts): Harvard University Press, 1938, pp. 521-523. 
en las páginas de su obra, y más aún si tenemos en cuenta que lo tuvo que ver con sus propios ojos en 1932. A ello hay que añadir que en las páginas de su obra sí aludió explícitamente a un compartimento de retablo de época gótica conservado en la sacristía. Mostraba la representación de san Juan Evangelista, y el especialista norteamericano alabó su gran calidad:

"[...] I well remember the aesthetic excitement that it stirred in me when I suddenly came upon it during a summer's day of 1932, by comparison with the mediocre works of Pedro García's pupils and of Espalargucs and his school, which, so superabundant in this region [...]".

Lo atribuyó al Maestro de Verdú, hoy identificado con el pintor leridano Jaume Ferrer II ${ }^{79}$, filiación un tanto desenfocada que hemos matizado en fecha reciente acercando la obra a Pere García de Benavarri ${ }^{80}$. Sin lugar a dudas, se trata de un compartimento perteneciente a un retablo distinto al pintado por Pedro de Aponte, pero que hablemos de él aquí se justifica por la extrañeza que nos causa que Post lo mencionase y que no citase, en cambio, el majestuoso retablo que presidía el presbiterio de la iglesia. Todo ello nos llevó en su momento a afirmar que, probablemente, el retablo no fue destruido, sino vendido en una fecha indeterminada que deberíamos situar entre 1928, año en que fue tomada la fotografía del conjunto, y 1932, cuando Post visitó Azanuy ${ }^{81}$. Sea como fuere, la aparición en las reservas del Museo de Zaragoza de las mencionadas puertas del conjunto ahora nos hace ser escépticos con esta posibilidad.

Si nos centramos en la fotografía del retablo (Fig. 11), vemos que se trataba de un conjunto que combinaba pintura y escultura articulado a partir de cinco calles, la central ligeramente más ancha que las laterales. El nicho central estaba presidido por una escultura en madera de la Virgen con el Niño, emplazada sobre una pequeña peana y rodeada por seis ángeles dispuestos alrededor. Este grupo escultórico se coronaba y protegía mediante un dosel que interiormente presentaba una simulación de abovedamiento gótico. A partir de dicho elemento se proyectaban verticalmente tres tubas de dos tramos de altura y tres paños cada una, estos últimos decorados con profusa tracería calada. Cada una de las tubas se remataba con sendos coronamientos florales sobremontados por las tres figuras escultóricas que integraban el Calvario, el Crucificado, la Virgen y san Juan Evangelista, que también hallamos en los retablos de Cintruénigo y Olite. Por detrás de dichas figuras se disponía el compartimento cumbrero del retablo, que mostraba una fondo neutro con estrellas. Justo por encima del Crucificado, remataba el conjunto una imagen tallada de Cristo Salvador que bendecía con su mano derecha y sostenía el orbe terráqueo con la izquierda. En el retablo de Ágreda, es una escultura tallada de Dios Padre la que corona el conjunto.

El ciclo iconográfico representado en las calles laterales discurría en tres niveles o pisos. A la vista de la fotografía conservada, detectamos que el retablo sufrió en fecha indeterminada - seguramente coincidiendo con la reforma de la iglesia en época barroca - algún tipo de remontaje o intervención que

79 POST, ref. 78, pp. 521-523, fig. 191.

80 VELASCO, ref. 74, vol. I, p. 214.

81 VELASCO, ref. 74, vol. I, p. 215. 
alteró su estructura original y la disposición de los compartimentos. En este sentido, la disposición que se advierte impide una lectura ordenada y lógica, a lo que debe añadirse que la estructura incorporaba compartimentos de otros retablos anteriores que se colocaron en las inmediaciones de la predela, en el tercio inferior del conjunto (Fig. 14). Entre ellos hay cuatro que claramente apuntan a la segunda mitad del siglo XV, de los que ya nos ocupamos en su momento ${ }^{82}$. Tres de ellos parecen formar un grupo unitario, ya que muestran imágenes de cuerpo entero de santos, ubicados frente una especie de cortinaje recortado por los nimbos de cada uno de ellos, además de una filacteria con el nombre del santo. El cuarto compartimento, en cambio, con un santo obispo, presenta las mismas características que el san Juan Evangelista mencionado más arriba y tiene, además, unas dimensiones un poco diferentes de las tablas anteriores. Desafortunadamente, la definición de la fotografía no permite que a través de software informático podamos acercarnos lo suficiente para facilitar la identificación de los

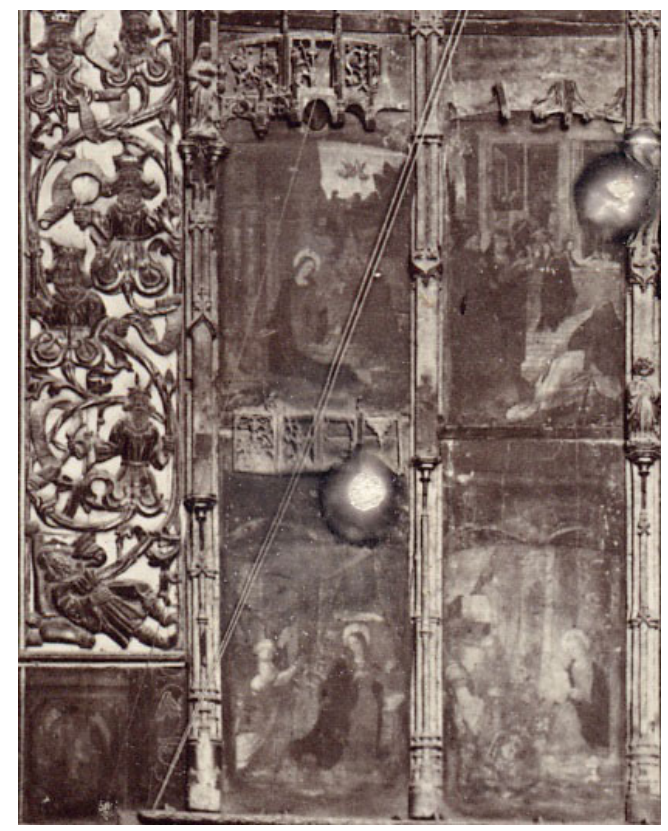

Fig. I2: Pedro de

Aponte. Retablo mayor

de Santa María. Detalle

de los compartimentos

laterales. Azanuy,

iglesia parroquial.

Foto: Archivo Barón de

Valdeolivos de Fonz.

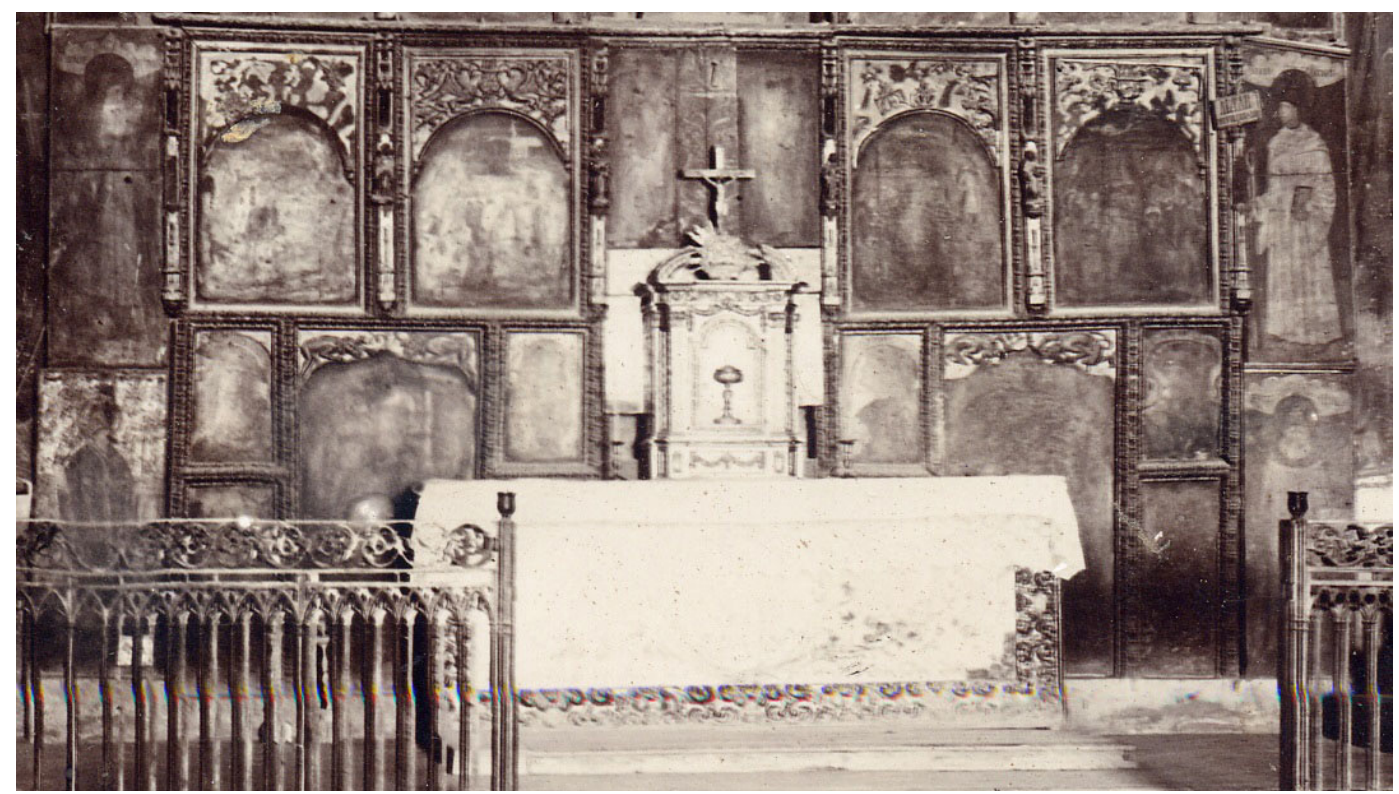

Fig. I3: Pedro de Aponte. Retablo mayor de Santa María. Detalle de los compartimentos laterales. Azanuy, iglesia parroquial. Foto: Archivo Barón de Valdeolivos de Fonz.

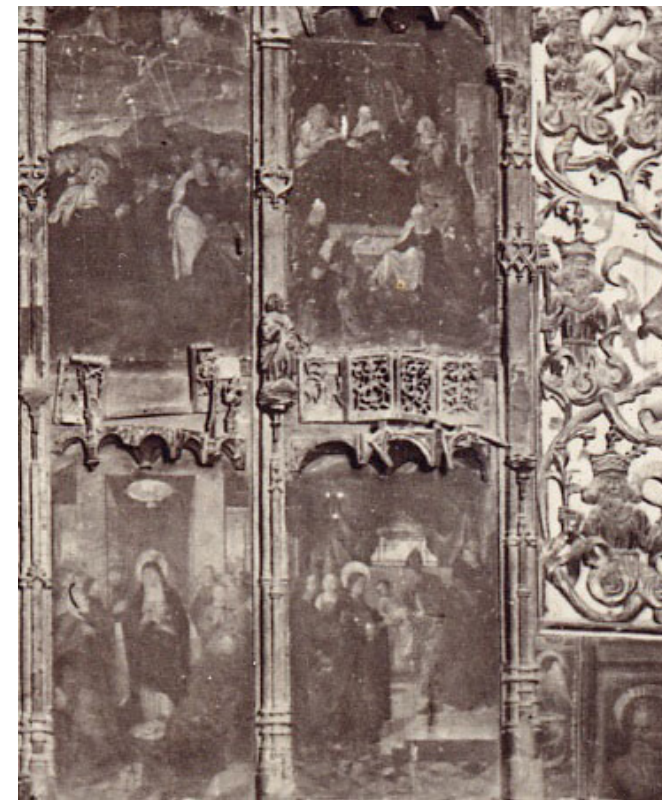

Fig. I4: Pedro de Aponte. Retablo mayor de Santa María. Detalle de los compartimentos de la parte baja. Azanuy, iglesia parroquial. Foto: Archivo Barón de Valdeolivos de Fonz.

82 VELASCO, ref. 74, vol. I, pp. 214-215. 
santos y la observación atenta del estilo. En este parte baja del retablo se intuyen otros compartimentos que quizás tampoco pertenecieron al retablo quinientista y que debieron ser añadidos en el marco de la remodelación mencionada.

Las tablas pintadas del conjunto mostraban diferentes episodios de la vida de la Virgen, puesto que el templo estaba dedicado a María. Aparte, es posible que la predela estuviese dedicada a la Pasión, aunque la escasa nitidez de la imagen impide aseverarlo con rotundidad. Como ya se ha apuntado, la ordenación de los compartimentos era completamente aleatoria, por lo que ofrecemos el listado de acuerdo al relato evangélico: Nacimiento de la Virgen, Presentación de la Virgen en el Templo, Anunciación, Visitación, Natividad, Epifanía, Presentación de Jesús en el Templo, Resurrección, Ascensión, Pentecostés, Dormición de María y Coronación de la Virgen (Figs. 12 y 13). Las entrecalles interiores estaban presididas por pilares de sección arquitectónica que a la altura del primer piso incorporaban mensulillas sobre las que reposaban santos o ángeles esculpidos en madera. A la altura del tercer piso, las mensulillas eran dobles y se doblaban también las figuras, mientras que en el cuarto nivel los pináculos se remataban con espigas. En cuanto a las dos entrecalles exteriores, las que separaban los compartimentos de las calles laterales de los extremos y el guardapolvo presentaban las figurillas a la altura del primer y segundo piso, ya que el tercero solamente lo ocupaban las espigas de remate de los pináculos.

La mazonería comprendía también, por un lado, tubas facetadas de tracería que remataban cada uno de los compartimentos, algunas de las cuales se encontraban en mal estado o habían desaparecido; y, del otro, el guardapolvo que recorría el perímetro exterior del conjunto. Presentaba una anchura considerable sobre la que se desarrollaba un tema altamente propicio en relación al ciclo mariano representado en los compartimentos, el del Árbol de Jesé, que mostraba la genealogía de Cristo y María $^{83}$. De acuerdo a lo tradicional en la representación del tema, en la base del tramo de guardapolvo del costado izquierdo aparecía la figura recostada de Jesé (Fig. 12), de cuyo vientre surgían los tallos y ramificaciones que configuraban el árbol, las cuales eran habitadas por las representaciones de los doce reyes dela tribu de Judá (David, Salomón, etc.). Había seis en cada uno de los dos tramos más largos del guardapolvo, mientras que en el tramo izquierdo del nivel superior se detecta la presencia de uno más, ya que lucía corona y cetro. Cada uno de los tramos largos de los costados se remataba con tres mensulillas con figuras. En la de la izquierda encontrábamos ángeles, mientras que en las tres del costado derecho aparecía una figura de bulto de la Virgen, obviamente como parte de la genealogía del Hijo de Dios, y lo que parece un ángel. La tercera figura de ese lado había desaparecido. Las ramificaciones del árbol culminaban en la mencionada representación escultórica de Cristo Salvador de la cúspide.

Debe señalarse que la presencia del árbol de Jesé en el guardapolvo de retablos del Primer Renacimiento en la Corona de Aragón debió ser bastante habitual, puesto que conservamos algún ejemplo más y conocemos otros a través de la documentación. En cuanto a las obras conservadas, debe men-

83 Sobre la iconografía del tema, de amplia bibliografía, véase el estudio ya clásico de WATSON, A. The Early Iconography of the Tree of Jese. Oxford: Oxford University Press, 1980 o el trabajo más reciente de GREEN, S. L. Tree of Jesse Iconography in Northern Europe in the Fifteenth and Sixteenth Centuries. Nueva York: Routledge, 2018. Puede citarse también la síntesis de MANZARBEITIA, S. El árbol de Jesé. Revista Digital de Iconografía Medieval, 2009, I (2), pp. 1-8. 
cionarse el retablo mayor de la iglesia de Sant Feliu de Girona, buen parte del cual hoy se conserva en el Museu d'Art de Girona. Lo realizó Pedro Robredo, fustero de Burgos establecido en Girona, que lo contrató en 1507. El documento especifica que el guardapolvo debía incluir figuras "de mig bulto", esto es, en bajo relieve, lo que conecta lo conservado en Girona con la técnica de realización del guardapolvo de Azanuy. Igualmente, se comenta que en el guardapolvo debían representarse a Jesé y los doce reyes, seis a cada lado, como en nuestro retablo. En el contrato se menciona también que debía realizar seis pilares que habían de descansar sobre la predela, con cuatro imágenes "de bulto" en cada uno de ellos, lo que nos emplaza ante una solución análoga a la que se implementó en el retablo de Azanuy. En 1509 la obra estaba completamente terminada ${ }^{84}$, justo el mismo año en que sabemos que Pedro de Aponte trabajaba en el retablo de Azanuy.

No fue la única ocasión en la que Robredo contrató una obra de este tipo con esa misma iconografía. Así, en 1512 acordó la realización del guardapolvo del retablo mayor de la iglesia de Santa Águeda de Xèrica, en Castellón" ${ }^{85}$. En el documento se especifica que el mazonero había de realizar "las quatro polseras para el dicho Retaulo mayor de la dicha esglia de medio bulto de buena fusta de pino de tres palmos de amplaria de la Ystoria de Gesé ço es de la generació de los reyes de la decendencia de nuestra Senyora la Virgen María”. Como vemos, tanto la técnica de realización en bajorrelieve como el tema representado fueron los mismos, por lo que puede deducirse que Robredo debía estar especializado en la realización de guardapolvos de tracería caladada como los de Girona y Xèrica, que se llevaron a cabo por los mismo años que el de Azanuy.

En cuanto a la predela (Fig. 14), la mala definición de la fotografía nos impide efectuar una interpretación ajustada de los episodios representados en cada uno de los cuatro compartimentos, pero es muy posible que estuviesen dedicados a la Pasión, como en los retablos que Aponte realizó para Ágreda, Cintruénigo y Olite. En este sentido, el del extremo derecho parece que representaba el Descendimiento de Cristo de la cruz. Los cuatro compartimentos presentaban igualmente un interesante trabajo de mazonería en la parte superior con motivos vegetales organizados a partir de algo similar a copas o triunfos, lo que permite establecer un nexo de unión con los repertorios de las formas "al romano", las propias del Primer Renacimiento. Hay que llamar la atención también sobre los pináculos de tradición gótica que separaban cada una de las casas, que en su parte central presentaban figuras esculpidas de menores dimensiones a las que vemos en los pináculos de las entrecalles del cuerpo superior. Debemos suponer, por otro lado, que la modificación que transformó el retablo hizo desaparecer el sagrario central que debía presidir el bancal.

En los extremos del retablo debían situarse dos puertas, que tras la transformación fueron recolocadas en el nivel inmediatamente inferior al de la predela, junto a otros compartimentos que en origen pertenecieron a otros retablos (Fig. 14). Es difícil señalar qué personajes mostraban porque la fotogra-

84 Sobre el retablo de Sant Feliu de Girona y los datos que aquí aportamos, véase RUIZ, F. y YEGUAS, J. L'antic retaule major de l'església de Sant Feliu de Girona. Una visió de conjunt d'un retaule-reliquiari. Retrotabulum. Estudis d'art medieval, 2016, 20, pp. 1-120[consulta: 8 agosto 2020]. Disponible en: http://www.ruizquesada.com/index.php/es/retrotabulum-eses/186-retrotabulum-n20lantic-retaule-major-de-lesglesia-de-sant-feliu-de-girona-una-visio-de-conjunt-dun-retaule-reliquiari. Los autores citan el retablo de Azanuy como paralelo para el gerundense, a la vista de las relaciones iconográficas que afectan a los guardapolvos de ambos conjuntos. 


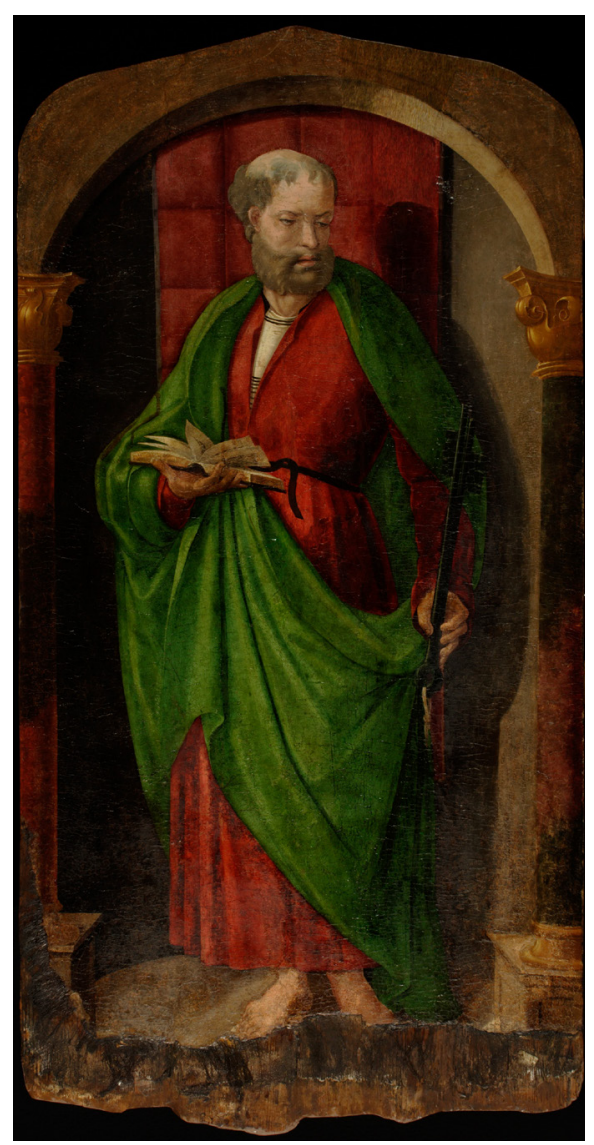

Fig. I5: Pedro de Aponte. San Pedro. Compartimento procedente del retablo mayor de Azanuy. Zaragoza, Museo de Zaragoza. Foto: Museo de Zaragoza. José Garrido.

fía no lo permite a ciencia cierta, aunque lo habitual era encontrar a san Pedro y san Pablo. Sea como sea, si tratamos la imagen con el software informático adecuado (Photoshop), identificamos dichas puertas gracias al trabajo de mazonería que presentaban en la parte superior, organizado a partir de dos bestias afrontadas encima de un arco conopial, y también por el formato que presentan, algo más ancho que el resto de compartimentos que se ven en la parte baja del conjunto. Si nos fijamos en la copia en papel de la fotografía conservada en el Archivo Histórico Provincial de Huesca, que presenta algo más de iluminación que el archivo digital del cliché de vidrio del Archivo Barón de Valdeolivos (Fig. 14), apreciaremos algún detalle añadido de lo representado en las puertas. Justo debajo de la citada crestería de mazonería que ambos compartimentos presentaban en la parte superior, se intuye un arco de medio punto pintado, especialmente en la puerta que queda a la derecha del sagrario (según el punto de vista del espectador). En cuanto a la puerta que se emplaza a la izquierda del sagrario, es interesante fijarse en una suerte de pequeños cuadrados que se intuyen en el fondo.

Estos detalles formales se corresponden con los que muestran dos puertas de retablo con las imágenes de San Pedro (149 x $76 \mathrm{~cm})$ y San Pablo $(153$ x $76 \mathrm{~cm})$ conservadas en el Museo de Zaragoza (inv. NIG. 9445 y 9446), atribuidas por Carmen Morte a Pedro de Aponte hace escasos años (Fig. 15 y 16$)^{86}$. Si nos fijamos en dichas tablas, vemos que ambas presentan un fondo con un tejido donde aparecen pliegues o dobleces que forman cuadrados, como los que hemos identificado en la fotografía antigua. Igualmente, vemos que ambos personajes se ubican debajo de un arco de medio punto soste- 
nido por columnas, un arco que morfológicamente reproduce las formas y que tiene la misma anchura y luz que el que hemos identificado en la imagen en cuestión.

Las tablas ingresaron en el museo zaragozano en 1941 a través del Servicio de Defensa del Patrimonio Artístico Nacional (SDPAN), el órgano gestor de las devoluciones patrimoniales del gobierno franquista. Procedían de Barcelona, donde se encontraban el 11 de junio de 1939 en los depósitos del SDPAN, en el Palacio Nacional de Montjuïc. El 21 de junio de 1939 ya se hallaban en la Iglesia del Carmen de Zaragoza, otro de los depósitos de dicho organismo. Dos años después de su llegada a la capital aragonesa, ingresaban en el fondo del antiguo Museo Provincial en calidad de depósito, al igual que otras obras que no fueron reclamadas por sus legítimos propietarios, siguiendo un procedimiento habitual en otras regiones del estado ${ }^{87}$. La documentación relacionada con la llegada de ambas puertas a Zaragoza y su ingreso en el museo no mencionaba el origen en Azanuy, pero es evidente que debía existir algún tipo de indicio sobre su procedencia aragonesa desde el momento en que fueron trasladadas desde Barcelona a la capital zaragozana junto a otras obras de arte. Es interesante señalar que Morte ya intuyó que el origen de las puertas podía hallarse en Azanuy, conclusión a la que llegó a través de algunos indicios de tipo físico. En este sentido, señaló que debía tenerse en cuenta que las tablas fuesen recuperadas después de la finalización de la Guerra Civil española y que se observasen daños en la superficie pictórica y el soporte, algunos de ellos producidos por una exposición prolongada a una fuente de calor. Ello permitía especular con que ambos compartimentos formasen parte del retablo de Azanuy, del que se tenía constancia que había sido quemado durante la contienda bélica $^{88}$. Hoy, gracias a la comparación de las tablas con la fotografía antigua del retablo, estamos en condiciones de confirmar las sospechas de Morte.

Por otro lado, si nos fijamos en los compartimentos del retablo de Azanuy, su estilo concuerda a la perfección con el resto de obras conocidas de Pedro de Aponte. Aunque la fotografía del conjunto no permite analizar con detalle el estilo del pintor, el tratamiento de la imagen con el adecuado software informático (Photoshop) permite acercarnos mínimamente a los compartimentos para identificar la mano del maestro y, también, algunas composiciones que hallamos en otros de sus trabajos. Es el caso del retablo de Olite, donde a pesar de ser un conjunto correspondiente al período tardío del pintor, hallamos un ciclo mariano que incluye la mayoría de escenas representadas en Azanuy. Así, por ejemplo, vemos una Anunciación con el lecho dispuesto en diagonal a la derecha de la composición, y con los personajes ubicados de forma análoga. Lo mismo puede afirmarse para la Resurrección, donde observamos una disposición de Cristo y el sepulcro muy similares a las de Azanuy (Fig. 17). En el retablo de Cintruénigo también hallamos una composición muy similar, aunque debe tenerse en cuenta que los compartimentos del cuerpo del retablo no son de Aponte, lo que no significa que no pudiese facilitar los modelos. En cuanto al Nacimiento de la Virgen (Fig. 13), la composición es sensiblemente diferente a la de Olite al no ubicarse el lecho en diagonal, sino de forma plana en relación

87 Sobre el SDPAN, su actuación en Zaragoza y los bienes ingresados en el Museo de Zaragoza procedentes de lugares de Cataluña, véase MAÑAS, L. y SARNAGO, E. Las obras de arte del Museo de Zaragoza recuperadas por el Servicio de Defensa del Patrimonio Artístico Nacional. Seminario de Arte Aragonés, 1999, 48, pp. 499-523, que aluden explícitamente a las tablas que nos ocupan (p. 506 y 514).

88 MORTE, ref. 86, p. 156. 


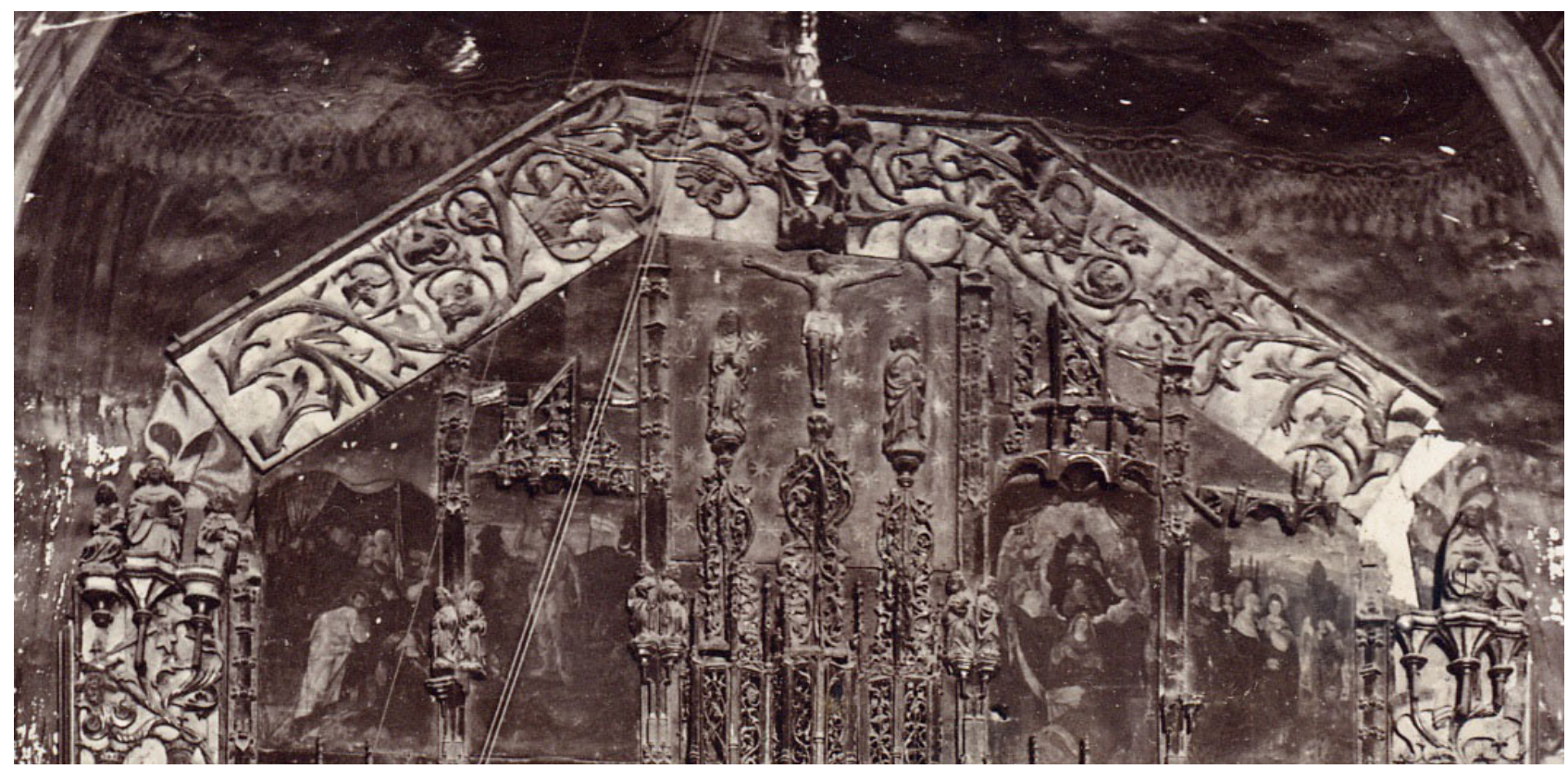

Fig. I7: Pedro de Aponte. Retablo mayor de Santa María. Detalle de los compartimentos de la parte alta. Azanuy, iglesia parroquial. Foto: Archivo Barón de Valdeolivos de Fonz.

al plano pictórico, como en el grabado de Durero sobre el tema, que en Azanuy pudo tomarse como fuente de inspiración.

Las composiciones de Azanuy muestran el característico amontonamiento de personajes tan propio de Aponte, mientras que las figuras se contorsionan y adoptan posturas forzadas como es habitual en sus trabajos. Son personajes de gran expresividad y dramatismo en sus acciones, pero no responden a patrones formales naturalistas. En este sentido, una deformitas protomanierista invade sus rostros y cuerpos, una forma de expresividad del feismo que Aponte cultivó asiduamente en sus retablos, y que comparte con otros pintores coetáneos de la Corona de Aragón, como Joan de Borgonya, activo en Cataluña en esos mismos años ${ }^{89}$.

\section{Un nuevo retablo para Pedro de Aponte}

Hace unos años Carmen Morte dio a conocer una tabla con Santiago y donante $(148 \times 66,5 \mathrm{~cm})$ conservada en una colección particular, atribuyéndola acertadamente a Pedro de Aponte (Fig. 18) ${ }^{90}$. El santo aparece de cuerpo entero, con la cabeza ligeramente ladeada hacia su derecha. Sostiene un libro en la mano y luce los atributos habituales de peregrino, esto es, el bordón y el sombrero con la venera de peregrinaje a Compostela. Va descalzo y se intuye la presencia de un nimbo de rayos dorados detrás de la cabeza. Una donante femenina, con toca blanca de viuda, se arrodilla ante él. Se trata, sin duda, de la promotora del retablo, de quien desconocemos su identidad. Ambos personajes aparecen en un espacio delimitado por una estructura arquitectónica de sillares regulares por encima

89 Sobre Joan de Borgonya, véase GARRIGA, J. Joan de Borgonya, pintor del XX capítulo de la orden del Toisón de Oro. En: Ernest BELENGUER, coordinador. De la unión de coronas al Imperio de Carlos V. Madrid: Sociedad Estatal para la Conmemoración de los Centenarios de Felipe II y Carlos V, 2001, vol. III, pp. 121-180.

90 MORTE, ref. 4, pp. 66-67, fig. 31, a partir de un cliché del Institut Amatller d'Art Hispànic de Barcelona. 
de la cual se intuye un cielo azul. Sobre el muro reposa una dosel textil de tono granate, ribeteado en negro, que actúa a manera de paño de honor y cubre al santo. El pavimento se ha articulado a partir de una receta compositiva tradicional a base de diagonales, y lo integran losetas de dos tonos rosáceos con una forma cuadrangular en la parte central. En el retablo de Grañén encontramos algún pavimento con baldosas pintadas en doble color rosa, como el compartimento que muestra a San Juan Evangelista ante el Emperador Domiciano, e incluso algún otro donde aparece la misma forma cuadrangular en el centro de las losetas, como el Milagro de la copa envenenada. Por otro lado, en nuestra tabla las sombras de ambos personajes se proyectan sobre el pavimento, lo que deviene un recurso habitual del pintor que pone de manifiesto un cierto dominio del tratamiento lumínico.

La atribución a Aponte de la tabla es bastante clara. Vemos, por ejemplo, que Santiago sostiene el libro de la misma forma que lo hace san Pablo en el retablo de Azanuy (Fig. 16) o san Felipe en el guardapolvo del retablo de Olite (Fig. 7), dándose también coincidencias en la morfología y posición de los dedos. Santiago y la donante

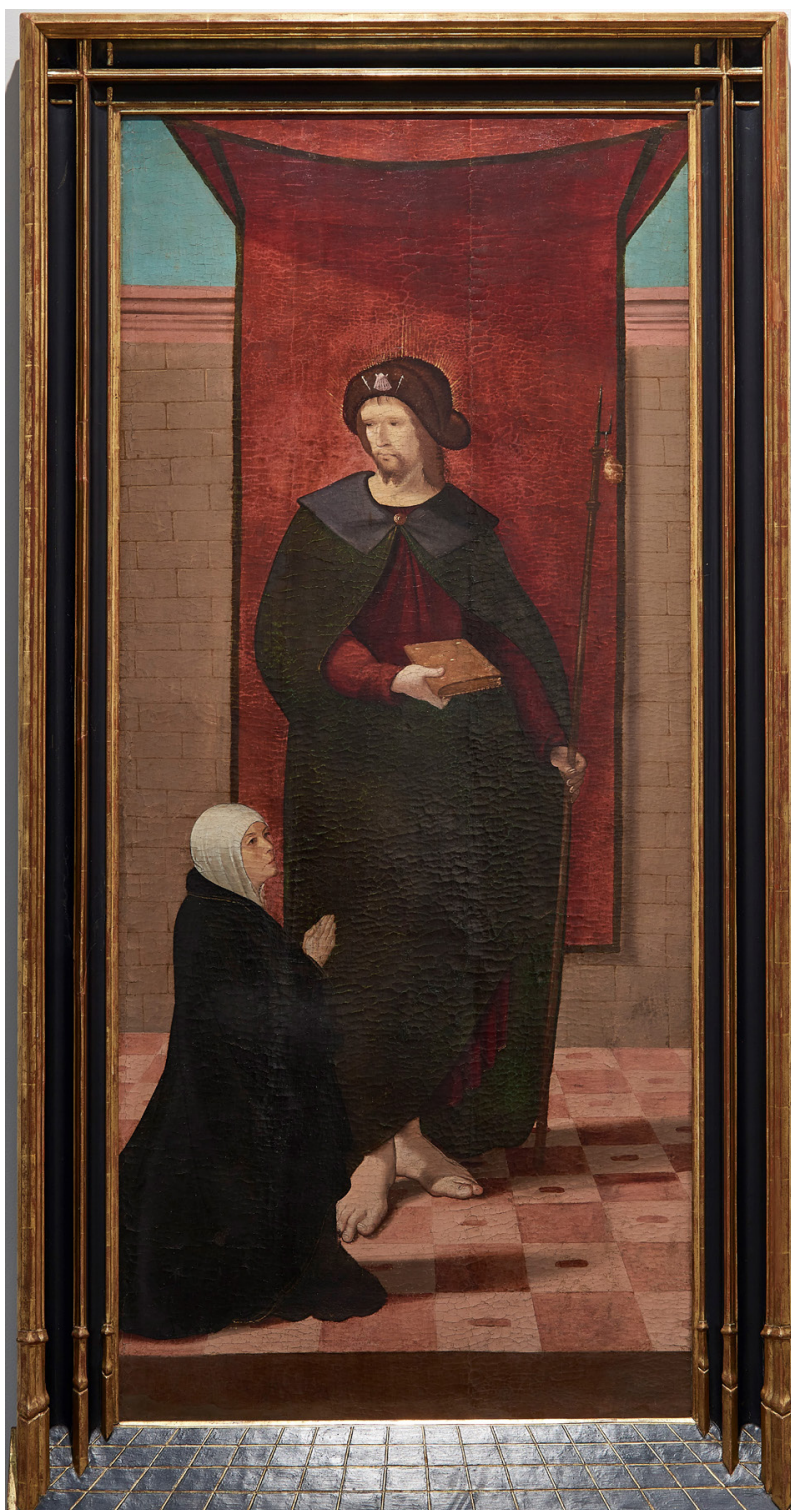

Fig. I8: Pedro de Aponte. Santiago y donante. Lisboa, Museu Nacional da Arte Antiga. Foto: (C) MNAA, Paulo Alexandrino, 2017. reproducen prototipos habituales en la obra del pintor, como apreciamos al comparar a la segunda con la María que aparece en la Disputa Jesús con los Doctores en Olite. En esa misma escena, el rostro de Jesús, aunque sin barba, presenta rasgos muy parecidos a los de Santiago. La posición de la donante, de perfil, con las manos juntas en señal de oración y luciendo toca blanca, es la misma que muestra la Virgen en la Ascensión del mismo retablo navarro. El perfil del rostro de la donante repite, igualmente, los mismos rasgos que el san Juan Evangelista de uno de los compartimentos de Olite. El de Santiago recuerda al de san Mateo por la posición de la cabeza, aunque en este se detecte un expresionismo más acusado; y también al judío de avanzada edad, con cayado, que vemos en el compartimento del Ecce Homo del retablo de Cintruénigo (Fig. 5).

A pesar de estos claros vínculos con las obras más tardías del pintor, en nuestra opinión, las concomitancias más evidentes se dan con obras anteriores, como el retablo de Azanuy, de hacia 1509, o el de Grañén, que Aponte materializó entre 1511 y 1513. En este sentido, el tipo de rostro de Santiago recuerda muy directamente a los de san Pedro y san Pablo en Azanuy, o a los de los apóstoles 

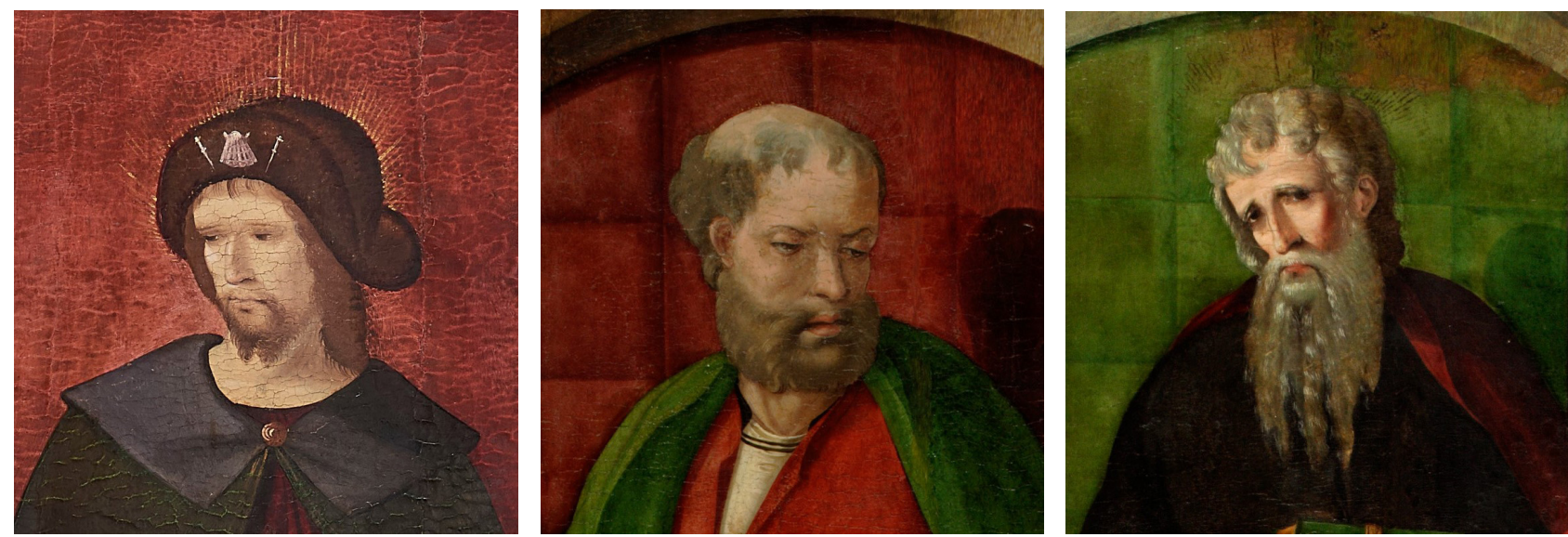

Fig. 19: Pedro de Aponte. De izquierda a derecha y de arriba a abajo: Santiago y donante (detalle), San Pedro procedente de Azanuy, San Pablo procedente de Azanuy, San Judas Tadeo del retablo de Grañén y San Pablo del retablo de Grañén.
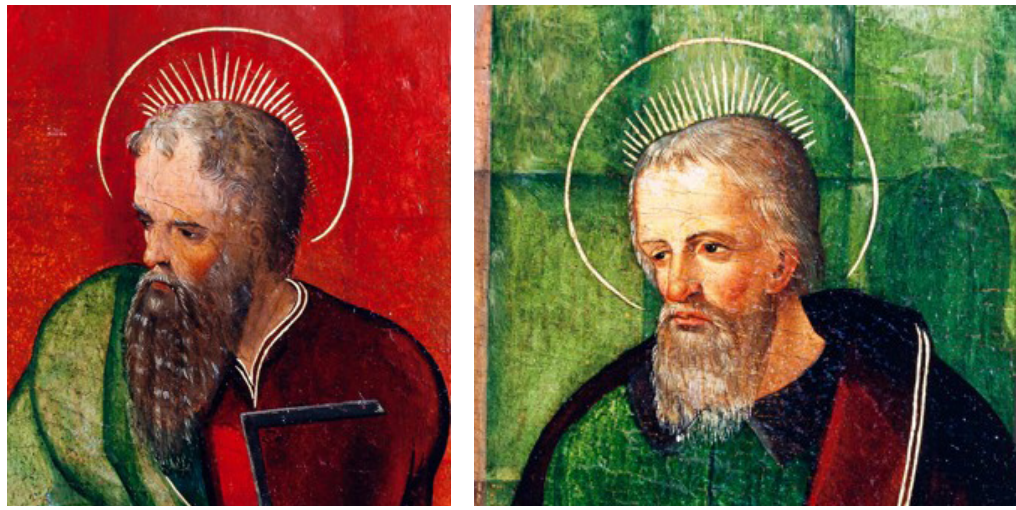

de Grañén, por el tratamiento suave y vigoroso, por el ligero sombreado en la cara o la torsión del cuello (Fig. 19). Uno de los paralelos más claros, con todo, lo hallamos en el Martirio de San Juan Evangelista del retablo de Grañén, en el personaje barbado que aparece a la izquierda del sayón con camisa verde. Alguna de las marías del Descendimiento de Ágreda también pueden ponerse en conexión nuestra donante, especialmente por el tratamiento de las cabezas cubiertas con toca. Además, en el episodio de la Prédica de Santiago del retablo de Grañén encontramos un personaje a la izquierda de la composición, de perfil y que se apoya en un bastón, con un rostro muy semejante al de nuestra donante. Entre el resto de personajes de la escena vemos diversos personajes femeninos con tocas blancas igualmente muy parecidos. Todavía con la donante, debemos apuntar que mantiene claros vínculos con el personaje femenino, igualmente de perfil, con toca blanca y las manos juntas, que aparece en el compartimento con el Ángel Guardián del Paraíso en el retablo de San Sebastián de Bolea, realizado hacia 1503. Lo mismo puede afirmarse para la María que encontramos en el Cristo camino del Calvario en el retablo de Ágreda.

Poco más se supo de la tabla de Santiago y donante después de haber sido dada a conocer por Morte. Lo interesante es que la obra apareció en subasta el pasado 2009 en Nueva York con una exótica atribución al Maestro de Lourinhã, un anónimo portugués ${ }^{91}$. En dicha venta fue adquirida, precisamente, por un coleccionista portugués. Previamente, se había podido ver expuesta temporalmente en el Museo de Bellas Artes de Caracas, en 1956 2 . La atribución al anónimo mencionado la

91 Christie's, Old Masters and 19th Century Art, 4 de junio de 2009, lote 8.

92 Se recogen estas informaciones en SEABRA, J. A. Dois mestres luso-flamengos: Mestre da Lourinhã e Frei Carlos. En: Primitivos Portugueses 1450-1550. O Século de Nuno Gonçalves. Lisboa: Museu Nacional de Arte Antiga, Athena, 2010, p. 158. 
debemos a Reis-Santos, quien en 1963 incluyó la obra entre las realizaciones del pintor ${ }^{93}$. Con todo, en 2010, a raíz de su participación en la exposición "Primitivos Portugueses 1450-1550. O Século de Nuno Gonçalves" que tuvo lugar en el Museu Nacional de Arte Antiga de Lisboa, José Alberto Seabra descartó dicha filiación y situó la obra en el contexto castellano, en el taller o círculo de Juan de Borgoña ${ }^{94}$. Con esta atribución la tabla fue adquirida en 2017 por el Estado portugués, que la ha depositado en el mencionado museo lisboeta ${ }^{95}$. A todo ello debe añadirse que tanto los responsables de la subasta de 2009, como los organizadores de la exposición de 2010, así como los responsables de la adquisición reciente, desconocían la adscripción de la obra al contexto aragonés y su atribución a Pedro de Aponte.

Tanto el estilo como las medidas certifican que un compartimento de retablo inédito con Santa Elena y el Emperador Constantino (176,5 x 96,5 cm), hoy en colección particular ${ }^{96}$, perteneció al mismo retablo que el panel hoy en Lisboa. La tabla muestra una representación de cuerpo entero de ambos personajes que aparecen agarrando con un paño en sus manos la Vera Cruz, el madero donde fue crucificado Cristo y que, según la leyenda, Elena y Constantino hallaron enterrado. La santa va coronada y sujeta con su otra mano la palma del martirio. Gira delicadamente la cabeza hacia el centro de la composición, y contorsiona su cuerpo gracias a un contrapposto suave. Viste una túnica verde de apariencia táctil y aterciopelada conseguida gracias al tratamiento de las texturas. El manto, de rojo intenso, otorga volumen a la figura y genera pliegues abundantes y bien resueltos.

En cuanto al Emperador Constantino, se encuentra en posición de tres cuartos y realiza un gesto con las piernas habitual en otros personajes de Aponte, el de adelantar uno de los pies, como hemos visto en el compartimento con Santiago y donante. Viste un traje corto de color morado y también aterciopelado, calzas rojas y manto verde y rojo, además de un sombrero que ciñe con su corona real. Sujeta una gran espada que apoya en el suelo. Su rostro presenta unos rasgos duros y afilados, con un sombreado muy característico en los personajes de Aponte. Detrás de los personajes, colgando del muro de fondo, vemos un paño de honor dorado con decoraciones de brocado realizadas con la técnica del estofado. La colgadura se sujeta al muro directamente con clavos, generando así una serie de pliegues que han sido especialmente bien resueltos por el pintor. El pavimento se ha articulado a partir de baldosas de tonos rosa idénticas a las de la tabla de Santiago y donante, con la misma forma cuadrangular en el centro que también se repite en alguna de las tablas del retablo de Grañén. Vemos, igualmente, cómo se proyectan sobre el suelo las sombras que generan los cuerpos de los personajes.

La tabla de Santa Elena y el Emperador Constantino, de procedencia desconocida, es un nuevo jalón en el relativamente exíguo catálogo de obras del pintor, pues a parte de sus obras documentadas y conservadas, hemos visto que se conocen escasos trabajos que se le hayan adscrito por la vía atributiva. A ello se une el hecho que pueda asociarse directamente al compartimento hoy custodiado en

93 REIS-SANTOS, L. O Mestre da Lourinhã, Lisboa, Artis, 1963, p. 7.

94 SEABRA, ref. 92, p. 159, con reproducción en color de la tabla (cat. 40).

95 Sobre la adquisición, véase Estado compra pintura "Santiago e Doadora" para o Museu Nacional de Arte Antiga. En: Diário de Notícias [en línea] [consulta 8 agosto 2020]. Disponible en: https://www.dn.pt/artes/estado-compra-pintura-santiago-e-doadora-parao-museu-nacional-de-arte-antiga-6248233.html.

96 No publicamos en este estudio la fotografía de la obra debido a que nos ha sido imposible obtener la autorización del actual propietario. 
Lisboa, con lo que ambas tablas pasan a integrar un nuevo conjunto de una cierta entidad. Morfológicamente, es significativo que este segundo compartimento sea unos $30 \mathrm{~cm}$ más alto y ancho que su compañero, lo que nos emplaza ante un retablo con paneles de dimensiones diferentes. Sea como sea, vemos que se mantienen las proporciones y la correlación de medidas entre ellos.

Desde el punto de vista estilístico tampoco hay duda sobre la integración de ambas tablas en un mismo conjunto. Lo confirma el hecho que los personajes aparezcan de cuerpo entero rodeados de una serie de elementos comunes, como son los respectivos muros de sillares del fondo, los paños de honor (aunque existan algunas diferencias entre los que aparecen en cada una de las tablas), el cielo azul y, sobre todo, los pavimentos con idénticas baldosas en ambos casos y la proyección de sombras sobre ellos. Debe señalarse también que en ambas tablas los personajes visten indumentos con los colores rojo y verde, combinación cromática habitual —a la que debemos añadir el azul de la tabla con Santiago - en los retablos de Pedro de Aponte, como por ejemplo, el de Grañén.

En cuanto a los paralelos que encontramos para la tabla de Santa Elena y Constantino entre las obras de Aponte, debemos citar en primer lugar dos de los desaparecidos compartimentos de San Martín de Buil, el de San Antonio Abad (Fig. 9) y el de San Miguel abatiendo al maligno (Fig. 10), donde volvemos a hallar figuras de cuerpo entero ubicadas ante un muro de fondo del que pende un tejido con decoraciones idénticas. Además, el rostro de Constantino no se halla lejos del que luce san Martín en el tercer compartimento de Buil (Fig. 8). En cuanto a santa Elena, el tipo de figura responde a modelos semejantes a los de las santas que aparecen en el guardapolvo del retablo de Olite, especialmente santa Quiteria. La posición de la cabeza, su mirada dulce y rasgos en general, recuerdan a los de Eva en el compartimento con la Expulsión del Paraíso del retablo de Ágreda. También debe citarse el personaje femenino con toca blanca, túnica azul y manto rojo que aparece en la Prédica de Santiago del retablo de Grañén, cuyo rostro es concomitante. Es también en este retablo donde hallamos uno de los paralelos más evidentes para Constantino, el san Bartolomé, que inclina la cabeza de forma absolutamente idéntica, presenta semejantes rasgos faciales e, incluso, el mismo sombreado en la frente y parte de la cara. El santo Tomás, aunque en posición invertida, también podría invocarse aquí, así como el personaje que viste de rojo en el Ecce Homo, o los personajes que aparecen en la escena de la Aparición de la Virgen del Pilar a Santiago y sus discípulos (Fig. 2). En ese mismo compartimento, el rostro de la Virgen aparecida recuerda directamente al de santa Elena.

En conclusión, vistas las similitudes señaladas, estos dos compartimentos formaron parte de un retablo realizado por Pedro de Aponte seguramente por los mismos años que realizó los de Grañén y Buil, esto es, hacia 1515 aproximadamente. Se desconoce la iglesia de origen del conjunto, pero lo más probable es que se tratase de alguna parroquia del entorno aragonés, puesto que en esos años todavía no había iniciado su andadura profesional por tierras navarras. Se ignora también la identidad de la donante femenina arrodillada ante Santiago en uno de los compartimentos, pero el hecho que lo haga sola, sin el marido, y con toca, podría indicar que era viuda y que encargó la obra en un momento en que ya ostentaba una edad avanzada. Así las cosas, no debe descartarse que el retablo fuese el testimonio de una voluntad testamentaria cumplida poco antes de morir, o incluso después. Es posible, en conclusión, que fuese un conjunto destinado a una capilla familiar y que tuviese connotaciones funerarias. 


\section{Apéndice documental}

\section{Doc. 1}

Archivo Histórico de Protocolos de Zaragoza, Pedro Garín, año 1509, fol. 127v

Zaragoza. 1509, 19 de agosto

Referenciado: MORTE, C. Pedro del Ponte o Aponte. En: Aragón y la Pintura del Renacimiento. Zaragoza: Museo e Instituto "Camón Aznar", 1990, p. 67; MORTE, C. El retablo mayor de la iglesia parroquial de Grañén. En: El retablo de Grañén. Huesca: Diputación de Huesca, 1992, p. 23; MORTE, C. Los maestros del retablo de San Miguel de Ágreda. En: El retablo de San Miguel de Ágreda (Soria). Historia y restauración. Soria: Caja Salamanca y Soria, 1997, p. 46

Transcripción: inédita

Eadem die Johan Ximénez fustero, Miguel Gil Palomar pintor, e Johan Chamorro pintor vezinos de Çaragoza simul [?] eius solvit [?] no revocando etc. procuradores [?] et mestre Pedro Pont pintor vezino de la mesma çiudat para que por ellos e acordamos e qualquiere de ellos pueda obligar sus personas y bienes a qualesquiere fiança et fianças eta qualesquiere obras por el dicho maestre Pedro Pont fazederas en el villa tugar [tachado] de Çanui sicut encargo.

E juraron no comavenir etc.

Testes Johan y Pedro

Eadem die maestre Johan de Pelayo sastre vezino de la ciudat de Çaragoça no revocando etc. procuradores [?] et mestre Pedro Pont pintor vezino de la mesma ciudat para que por él e en nombre suyo pueda obligarse su persona e bienes a qualesquiera fiança que faiese menester en una obra que el dicho mestre Pedro Pont tiene de fazer en la villa de Çanui [?]

Testes qui supra

Eadem die Francisco Pérez corredor de XX e Grabriel Álvarez brodador vezino de Çaragoza pro testes al dicho Pedro Pont pintor [?][?]

Testes qui supra 


\section{Doc. 2}

Archivo Histórico de Protocolos de Zaragoza, Pedro Garín, año 1509, fol. 132v

Zaragoza. 1509, 31 de agosto

Referenciado: MORTE, C. Pedro del Ponte o Aponte. En: Aragón y la Pintura del Renacimiento. Zaragoza: Museo e Instituto "Camón Aznar", 1990, p. 67; MORTE, C. El retablo mayor de la iglesia parroquial de Grañén. En: El retablo de Grañén. Huesca: Diputación de Huesca, 1992, p. 23; MORTE, C. Los maestros del retablo de San Miguel de Ágreda. En: El retablo de San Miguel de Ágreda (Soria). Historia y restauración. Soria: Caja Salamanca y Soria, 1997, p. 46

Transcripción: inédita

Eadem die Kathalina de Rubert alias del Pont muller del honorable mestre Pedro Pont vezino de Çaragoça no revocando etc. pro testes al dicho su marido a obligación que la obra de un retablo que el dicho su marido tiene de fazer en el lugar de Azanuy su persona e bienes et [?]

Testes maestre Johan Iamorro pintor e Johan de Sanvicén scudero habitantes en Çaragoça. 


\section{Bibliografía}

ABIZANDA, Manuel. Documentos para la historia artística y literaria de Aragón procedentes del archivo de protocolos de Zaragoza: Siglo XVI. Zaragoza: La Editorial, 1915-1917, 2 vols.

ACERETE, José María. Estudio documental de las artes en la Comunidad de Calatayud en el siglo XVI. Calatayud: Centro de Estudios Bilbilitanos, 2001.

ÁGREDA, Ana María. Los ornamentos en las iglesias zaragozanas. Siglos XVI-XVIII. Aportaciones al estudio de los talleres de bordado y de las artes textiles en Aragón en la Edad Moderna. Zaragoza: Institución "Fernando el Católico", 2001.

ÁGREDA, Ana María. Los ornamentos de la Seo de Zaragoza en el siglo XVI: el funcionamiento de la sacristía. En: María Isabel ÁLVARO y otros, coordinadores. Estudios de historia del arte: libro homenaje a Gonzalo M. Borrás Gualis. Zaragoza: Institución “Fernando el Católico”, 2013, pp. 47-59.

ANGULO, Diego. La pintura del Renacimiento en Navarra. Príncipe de Viana, 1943, XIII, pp. 421-444.

ANGULO, Diego. La pintura del siglo XVI (Ars Hispaniae, vol. XII). Madrid: Plus Ultra, 1954.

ANGULO, Diego. Pinturas del siglo XVI en Toledo y Cuenca. Juan de Borgoña y su escuela. Pedro de Aponte en Atri. Yáñez y Sebastián del Piombo. Archivo Español de Arte, 1956, XXIX, 113, pp. 51-54.

ARCO, Ricardo del. El pintor cuatrocentista Pedro de Aponte. Tablas inéditas. Arte Español, 1914, 3, pp. 106-125.

ARCO, Ricardo del. La pintura de primitivos en el Alto Aragón (conclusión). Arte Español, 1916, III (1), pp. $16-21$.

ARCO, Ricardo del. Catálogo Monumental de España: Huesca. Madrid: Instituto Diego Velázquez (CSIC), 1942,2 vols. ARCO, Ricardo del. Pedro de Ponte, o Aponte, pintor del Rey Católico. Boletín del Seminario de Estudios de Arte y Arqueología: BSAA, 1942-1943, tomo 9, pp. 59-77.

BALAGUER, Federico. Pintores zaragozanos, en protocolos notariales de Huesca. Seminario de Arte Aragonés, 1954, VI, pp. 77-89.

BARRACHINA, Jaime. Pedro de Aponte. Mare de Déu amb el Nen. En: La pintura gòtica hispanoflamenca. Bartolomé Bermejo i la seva època. Barcelona-Bilbao: Museu Nacional d'Art de Catalunya-Museo de Bellas Artes de Bilbao, 2003, pp. 292-295.

BOLOGNA, Ferdinando. Napoli e le rotte mediterranee della pittura. Nápoles: Società Napolitana di Storia Patria, 1977.

BRUÑÉN, Ana Isabel y SENAC, María Begoña. Retablo mayor del Convento del Carmen Calzado de Calatayud. En: IV Encuentro de Estudios Bilbilitanos. Actas I. Calatayud: Centro de Estudios Bilbilitanos, Institución "Fernando el Católico", 1997, pp. 315-320. 
CRIADO, Jesús. Las artes plásticas del Primer Renacimiento en Tarazona (Zaragoza). El tránsito del moderno al romano. Tvriaso, 1992, 10 (2), pp. 387-452.

CRIADO, Jesús. Una obra desaparecida del pintor Pedro de Ponte. El retablo de la Virgen de Calcena. 1527. Tvriaso, 1996, XII, pp. 271-277.

CRIADO, Jesús. La fábrica del monasterio jerónimo de Santa Engracia de Zaragoza, 1492-1517. Artigrama, 1998, 13, pp. 253-276.

CRIADO, Jesús. Relaciones entre la Ribera de Navarra y Aragón durante la época del Renacimiento. Cuadernos de la Cátedra de Patrimonio y Arte Navarro, 2008, 3, pp. 213-254.

CRIADO, Jesús, IBÁÑEZ, Javier. La introducción del ornato al romano en el Primer Renacimiento aragonés. Las decoraciones pictóricas. Artigrama, 2003, 18, pp. 293-340.

ECHEVERRÍA, Pedro. Policromía del Renacimiento en Navarra. Pamplona: Gobierno de Navarra, Departamento de Educación, Cultura y Deporte, 1990.

GAETA, Letizia. Juan de Borgoña e gli altri: relazioni artistiche tra Italia e Spagna nel 400. Galatina: Mario Congedo Editore, 2012.

GARRIGA, Joaquim. Joan de Borgonya, pintor del XX capítulo de la orden del Toisón de Oro. En: Ernest BELENGUER, coordinador. De la unión de coronas al Imperio de Carlos V. Madrid: Sociedad Estatal para la Conmemoración de los Centenarios de Felipe II y Carlos V, 2001, vol. III, pp. 121-180.

GAY MOLINS, María Pilar. Aportación al estudio de las artes en Zaragoza: 1500-1525. En: Congreso Jerónimo Zurita. Su época y su escuela. Zaragoza: Institución “Fernando el Católico”, 1986, pp. 425-434.

GREEN, Susan L. Tree of Jesse Iconography in Northern Europe in the Fifteenth and Sixteenth Centuries. Nueva York: Routledge, 2018.

IBÁÑEZ, Javier. Los cimborrios aragoneses del siglo XVI. Tarazona: Centro de Estudios Turiasonenses, 2006.

LATASSA Y ORTÍN, Félix. Biblioteca nueva de autores aragoneses que florecieron desde el año de 1500 hasta 1599. Pamplona: Oficina de Joaquín fray Domingo, 1798, 6 vols.

LEONE DE CASTRIS, Pierluigi. Atribuido al Maestro de Bolea (¿Pedro de Aponte?). Misal-breviario de Fernando el Católico. En: Los Reyes Católicos y la Monarquía de España. Valencia: Generalitat Valenciana, 2004, pp. 376-378.

LEONE DE CASTRIS, Pierluigi. Pittura e miniatura nella Napoli di Ferdinando il Cattolico. En: Fernando CHECA y Bernardo GARCÍA, coordinadores. El Arte en la corte de los Reyes Católicos. Rutas artísticas a principios de la Edad Moderna. Madrid: Fundación Carlos de Amberes, 2005, pp. 75-94.

MANZARBEITIA, Santiago. El árbol de Jesé. Revista Digital de Iconografía Medieval, 2009, I(2), pp. 1-8. 
MAÑAS, Laura, y SARNAGO, Elena. Las obras de arte del Museo de Zaragoza recuperadas por el Servicio de Defensa del Patrimonio Artístico Nacional. Seminario de Arte Aragonés, 1999, 48, pp. 499-523.

MARÍAS, Fernando. El largo siglo XVI. Madrid: Taurus, 1989.

MARTÍNEZ, Jusepe. Discursos practicables del nobilísmo arte de la pintura. Madrid: Akal, (edición a cargo de Julián Gallego), 1988

MERCADAL, Sebastián. España Mariana, o sea reseña histórica y estadística... Provincia de Huesca, Partidos de Fraga y Tamarite. Lleida: Imprenta de Francisco Carruez, 1873.

MONCAYO Y GURREA, Juan de. Poema trágico de Atalanta e Hipomenes. Zaragoza: Diego Dormer, 1656.

MORTE GARCÍA, Carmen. La personalidad artística de Pedro de Aponte a través del retablo de San Miguel de Agreda (Soria). En: Primer Coloquio de Arte Aragonés. Teruel: Diputación Provincial de Teruel, 1978, pp. 219-234.

MORTE GARCÍA, Carmen. La obra del pintor Pedro de Aponte o del Ponte en Navarra: los retablos de Santa María la Real de Olite y de San Juan Bautista de Cintruénigo. Príncipe de Viana. Anejo, 1986, 2-3 (Homenaje a José María Lacarra), pp. 565-590.

MORTE GARCÍA, Carmen. Documentos sobre pintores y pintura del siglo XVI en Aragón. I. Boletín del Museo e Instituto “Camón Aznar”, 1987, XXX, pp. 17-232.

MORTE GARCÍA, Carmen. Pedro del Ponte o Aponte. En: Aragón y la Pintura del Renacimiento. Zaragoza: Museo e Instituto “Camón Aznar”, 1990, pp. 65-78.

MORTE GARCÍA, Carmen. Introducción. En: Aragón y la Pintura del Renacimiento. Zaragoza: Museo e Instituto “Camón Aznar”, 1990, pp. 17-33.

MORTE GARCÍA, Carmen. El retablo mayor de la iglesia parroquial de Grañén. En: El retablo de Grañén. Huesca: Diputación de Huesca, 1992, pp. 17-84.

MORTE GARCÍA, Carmen. Fernando el Católico y las artes. En: Las artes en Aragón durante el reinado de Fernando el Católico (1479-1516). Zaragoza: Institución “Fernando el Católico”, 1993, pp. 155-198.

MORTE GARCÍA, Carmen. El retablo mayor del Pilar. En: El retablo mayor de la Basílica de Nuestra Señora del Pilar. Zaragoza: Gobierno de Aragón, 1995, pp. 56-106.

MORTE GARCÍA, Carmen. Los maestros del retablo de San Miguel de Ágreda. En: El retablo de San Miguel de Ágreda (Soria). Historia y restauración. Soria: Caja Salamanca y Soria, 1997, pp. 39-59.

MORTE GARCÍA, Carmen. El retablo. En: El retablo de San Miguel de Ágreda (Soria). Historia y restauración. Soria: Diputación Provincial, 1997, pp. 63-109. 
MORTE GARCÍA, Carmen. Pedro de Aponte en Bolea. Y una noticia de La Calahorra (Granada). Boletín del Museo e Instituto Camón Aznar, 1997, 67, pp. 95-122.

MORTE GARCÍA, Carmen. Los arzobispos de la Casa Real: Don Alonso, Don Juan y Don Hernando de Aragón (14781575). En: La Seo de Zaragoza. Zaragoza: Diputación General de Aragón, 1998, pp. 175-247.

MORTE GARCÍA, Carmen. Los retablos y sillería de coro en Santa María la Mayor. En: La villa de Bolea. Estudio histórico-artístico y documental. Zaragoza: Centro del Libro de Aragón, 2001, pp. 47-78.

MORTE GARCÍA, Carmen. El Maestro del Misal-Breviario Vaticano de Fernando el Católico. Boletín del Museo e Instituto “Camón Aznar”, 2002, LXXXIX, pp. 261-286 y 409-428.

MORTE GARCÍA, Carmen. Historia. En: El retablo mayor de la iglesia de Santa María de Olite. Historia y conservación. Pamplona: Gobierno de Navarra, 2007, pp. 13-123.

MORTE GARCÍA, Carmen. Del Gótico al Renacimiento en los retablos de pintura aragonesa durante el reinado de Fernando el Católico. En: María del Carmen LACARRA, coordinadora. La pintura gótica durante el siglo XV en tierras de Aragón y en otros territorios peninsulares. Zaragoza: Institución “Fernando el Católico”, 2007, pp. $335-372$.

MORTE GARCÍA, Carmen. Estudio histórico-artístico de una obra renacentista. En: El retablo mayor de la parroquia de San Juan Bautista de Cintruénigo. Historia y conservación. Pamplona: Gobierno de Navarra, 2009, pp. 11-78.

MORTE GARCÍA, Carmen. El retablo mayor de la colegiata de Bolea (Huesca): una aproximación al dibujo subyacente a través de la reflectografía de infrarrojos. En: Ximo COMPANY y otros, editores. El rol de lo hispano en la pintura medietarránea de los siglos XV y XVI. Lleida: Centre d'Art d’Època Moderna, 2009, pp. 206-267.

MORTE GARCÍA, Carmen. Pedro de Aponte. San Pedro. San Pablo. En: Carmen MORTE, directora. El esplendor del Renacimiento en Aragón. Zaragoza: Gobierno de Aragón, Museo de Bellas Artes de Bilbao, Generalitat Valenciana, 2009, p. 156.

MORTE, Carmen y CASTILLO, M. (2012): Estudio histórico-artístico. En: Carmen MORTE y Margarita CASTILLO, coordinadoras. El retablo mayor renacentista de Tauste. Zaragoza: Institución “Fernando el Católico”, 2012, pp. 11-113.

MORTE, Carmen y MANRIQUE, M. E. El doctor García Fernández de Carrascón, protomédico de S. S. Adriano VI y protector de la iglesia parroquial de San Miguel de Agreda. En: El retablo de San Miguel de Ágreda (Soria). Historia y restauración. Soria: Caja Salamanca y Soria, 1997, pp. 15-35.

MORTE, Carmen y otros. El Retablo Mayor de la Iglesia Parroquial de San Pablo de Zaragoza. Restauración 2006. Madrid: Ministerio de Cultura, 2007.

NAVAL, Antonio. Pedro del Ponte (Aponte). Tesis de licenciatura inédita, Universidad Complutense de Madrid, 1975 (con autoedición reciente del autor [2017] en https://www.antonionavalmas.net/IMG/pdf/del_ponte definitivo_para web_10-07-2018_.pdf) [consulta: 8 agosto 2020]. 
OLMO, Antonio. ¿Pedro de Aponte? Arqueta de la infanta María. En: Carmen MORTE, directora. El esplendor del Renacimiento en Aragón. Zaragoza: Gobierno de Aragón, Museo de Bellas Artes de Bilbao, Generalitat Valenciana, 2009 , p. 173.

PÉREZ, José María. Pintores valencianos medievales y modernos. Addenda. Archivo Español de Arte y Arqueología, 1935, XI(33), pp. 293-312.

PÉREZ SÁNCHEZ, Alfonso E. editor. La pittura in Europa, La pittura spagnola. Milán: Electa, 1995.

PÉREZ, Pilar. El pintor Juan Chamorro en El Castellar. Vida Alagonesa, 3, 1999.

PERRICIOLI, Alessandra. Un "Libro d'ore” della Bibliothèque Nationale di Parigi e alcune riflessioni sull'attività di miniatore del Maestro del retablo de Bolea. Prospettiva, 1998, pp. 91-95.

POST, Chandler Rathfon. The Catalan School in the Late Middle Ages (A History of Spanish Painting, vol. VII). Cambridge (Massachusetts): Harvard University Press, 1938.

POST, Chandler Rathfon. The Schools of Aragon and Navarre in the Early Renaissance (A History of Spanish Painting, vol. XIII). Cambridge (Massachusetts): Harvard University Press, 1966.

RAMOS, F. Javier. Nuevos datos documentales sobre el pintor Hernando Rincón de Figueroa. Boletín del Museo e Instituto “Camón Aznar”, 1996, LXVI, pp. 79-90.

REIS-SANTOS, Luis. O Mestre da Lourinhã, Lisboa, Artis, 1963.

RUIZ, Francesc y YEGUAS, Joan. L'antic retaule major de l'església de Sant Feliu de Girona. Una visió de conjunt d'un retaule-reliquiari. Retrotabulum. Estudis d'art medieval, 2016, 20, pp. 1-120 [consulta: 8 agosto 2020]. Disponible en: http://www.ruizquesada.com/index.php/es/retrotabulum-eses/186-retrotabulum-n20-lantic-retaule-major-de-lesglesiade-sant-feliu-de-girona-una-visio-de-conjunt-dun-retaule-reliquiari.

SALA Valdés, Mario de la. Estudios históricos y artísticos de Zaragoza. Zaragoza: Imprenta del Hospicio Provincial, 1933.

SEABRA, J. Alberto. Dois mestres luso-flamengos: Mestre da Lourinhã e Frei Carlos. En: Primitivos Portugueses 14501550. O Século de Nuno Gonçalves. Lisboa: Museu Nacional de Arte Antiga, Athena, 2010, pp. 156-173.

SERRANO SANZ, Manuel. Documentos relativos a la pintura en Aragón durante el siglo XV. Revista de Archivos, Bibliotecas y Museos, 1914, XXXI, pp. 433-458.

SILVA MAROTO, Pilar. Rincón de Figueroa, Fernando del. En: Museo del Prado [en línea] [consulta 8 agosto 2020 ]. Disponible en: http://www.museodelprado.es/enciclopedia/enciclopedia-on-line/voz/rincon-de-figueroa-fernando-del/.

SRICCIA SANTORO, Fiorella. Tra Aragona e Napoli: ricerce sul “Maestro di Bolea”. Prospettiva, 2009, 133, pp. $22-45$. 
VELASCO, Alberto. Para que sus deliberaciones y consejos no vayan herrados sino acertados. Gonzalo de la Caballería y el retablo de la capilla del Concejo de Zaragoza (1443). Tvriaso, 2014-2015, 22, pp. 295-340.

VELASCO, Alberto. Pintura tardogòtica a l'Aragó i Catalunya: Pere Garcia de Benavarri. Tesis doctoral inédita, Universitat de Lleida, 2015, 2 vols.

VELASCO, Alberto. Some questions about the Flemish model in Aragonese painting (1440-1500). En: Alberto VELASCO y Francesc FITÉ, editores. Late Gothic Painting in the Crown of Aragon and the Hispanic Kingdoms, Leiden-Boston, Brill, 2018, pp. 71-136.

VELASCO, Alberto. Spanish Paintings from 14th to 16th Centuries. Madrid-Londres: Caylus, Sam Fogg, 2019.

VELASCO, Alberto. y BERLABÉ, Carmen. Violència i estralls contra el patrimoni artístic lleidatà durant la guerra civil espanyola. En: Oriol DUEÑAS y Josep Lluís MARTÍN, editores. La Guerra Civil al Territori. Lleida, Tarragona $i$ Girona. Barcelona: Generalitat de Catalunya, 2017, pp. 171-245.

WATSON, Arthur. The Early Iconography of the Tree of Jese. Oxford: Oxford University Press, 1980.

YARZA, Joaquín. Política artística de Fernando el Católico. En: Ernest BELENGUER, coordinador. De la unión de coronas al Imperio de Carlos V. Madrid: Sociedad Estatal para la Conmemoración de los Centenarios de Felipe II y Carlos V, 2001, vol. III, pp. 15-30. 